\title{
COGNOVIT JUDGMENTS: AN IGNORED PROBLEM OF DUE PROCESS AND FUIL FAITH AND CREDIT
}

\author{
DAN Hopson, JR. $\ddagger$
}

Joe Little, a Tonganoxie, Kansas, farmer, borrowed money, by mail, from the Friendly Finance Company of Columbus, Ohio. Later Friendly got a judgment in Ohio and sued Joe on the judgment in Kansas. "How come?," asked Joe. "I've paid that note." Joe's lawyer replied: "I'm sorry, Joe, but you'll probably have to pay again. You signed a note with a cognovit clause down in the fine print. Even though the note was paid, the cognovit let Friendly sue you in Ohio without telling you. Now Kansas will have to go along with the Ohio judgment." "But that's not fair," said Joe. "Thereought-to-be-a-law!"1

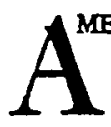

MERICAN COURTS have traditionally found a defendant subject to in personam jurisdiction in two situations: when he was personally served while voluntarily within the territory of the court, or when he voluntarily consented to the court's power. Consent, normally found in a cognovit clause or warrant of attorney, 2 has a long and honored history. But the time has come to re-evaluate this jurisdictional doctrine in the light of the recent advances in conflict of laws thinking.

With International Shoe Co. v. Washington ${ }^{3}$ the United States Supreme Court indicated a willingness to accept new ideas as to the limitation of the

$\dagger$ Associate Professor of Law, University of Kansas. A.B., 1951, LL.B., 1953, University of Kansas; LL.M., 1954, Yale University.

1 See, e.g., Hazel v. Jacobs, 78 N.J.L. 459, 75 Atl. 903 (1910). Contra, First Nat'1 Barik v. Cunningham, 48 Fed. 510 (D. Ky. 1891).

2 For an excellent discussion of these terms and the legal history of cognovit notes, see General Contract Purchase Corp. v. Max Keil Real Estate Co., 35 Del. 531, 170 Atl. 797 (Del. Super. Ct. 1933); First Nat'l Bank v. White, 220 Mo. 717, 120 S.W. 36 (1909); Note, 102 U. PA. L. REV. 524-28 (1954). The terms will be used interchangeably here.

There is considerable variation from state to state and from finance company to finance company on the typical wording of a cognovit clause. One reads: "The undersigned and each of them hereby authorized any attorney at law to appear in any Court of Record in the State of Ohio or in the United States, after this note becomes due under any of its conditions and waive the issuance and service of process and confess a judgment against the undersigned or any of them in favor of the legal holder hereof for the amount then appearing due hercon, together with actual court costs upon the entry of judgment, and thereupon to release all error and waive all right of appeal." This language is taken from the Ohio small loan form currently used by the General Acceptance Corporation, Allentown, Pennsylvania.

Other forms were supplied the author by attorneys in the finance industry. While the actual wording differs extensively, the basic coverage is the same.

3326 U.S. 310 (1945). 
cue process clauset on in personam jurisdiction. No longer need state courts and legislatures find in personam jurisdiction through contorted fictions of "presence" or "implied consent" arising out of "doing business"s or "dangerous instrumentalities." 6 Taking into account the changed facts of the business world, the Court granted freedom to the state to use as a test of in personam jurisdiction: "The quality and nature of the activity in relation to the fair and orderly administration of the laws ..."7 and "an "estimate of the inconveniences." "8 State courts and legislatures responded slowly at first, but with later encouragement from the United States Supreme Court, ${ }^{9}$ have protected the plaintiff's ability to sue in his own home state with increasing vigor. ${ }^{10}$

But does the new enlightenment-an enlightenment that says a technical, lawyer-only concept like in personam jurisdiction must follow the change in business practices of nationwide corporations-suggest the possibility of new restrictions on the defendant's liability to suit away from home?11 In other words, are changes also due in the consent area?

4 U.S. CONST. amend. XTV, § 1: "[N]o state shall . . . deprive any person of life, liberty, or property, without due process of law ...."

5 People's Tobacco Co. v. American Tobacco Co., 246 U.S. 79 (1918); Philadelphia \& R. Ry. v. McKibbin, 243 U.S. 264 (1917); International Harvester Co. v. Kentucky, 234 U.S. 579 (1914); Green v. Chicago, B. \& Q. Ry., 205 U.S. 530 (1907).

6 Hess v. Pawloski, 274 U.S. 352 (1927).

7 International Shoe Co. v. Washington, 326 U.S. 310, 319 (1945).

8 Id. at 317, quoting from Hutchinson v. Chase \& Gilbert, 45 F.2d 139, 141 (2d Cir. 1930). For another wording see RestateMENT (SECOND), CoNflict of LAws $\$ 74$ (Tent. Draft No. 3, 1956): "A state has judicial jurisdiction over a person if the person's relationship to the state is such as to make the exercise of judicial jurisdiction reasonable." Comment b states: "[A] state does not have jurisdiction in the absence of some reasonable basis for exercising it. . . . The principle cannot be defined more precisely than in terms of reasonableness or, following the lead of the Supreme Court of the United States, of "fair play and substantial justice." "

${ }^{9}$ See McGee v. International Life Ins. Co., 355 U.S. 220 (1957); But see Hanson v. Denckla, 357 U.S. 235 (1958).

10 See Ill. Rev. Stat. ch. 110, § 17 (1959); Minn. Stat. ANn. § 303.13 (3) (Supp. 1958); N.M. Stat. AnN. \$21-3-16 (Supp. 1959); Tex. Rev. Civ. Stat. AnN. art. 2031b (4) (Supp. 1960); WASH. RÈv. CODE § 4.28 .185 (Supp. 1959); Wis. Sess. Laws, 1959, ch. 226, § 15, amending WIs. STAT. $\$ \S 262.05,262.06$ (1957). Other states are interpreting old statutes to arrive at approximately the same result. See, e.g., Heury R. Jahn \& Son v. Superior Court, 49 Cal. $2 d$ 855, 323 P.2d 437 (1958); Jarrard Motors Inc. v. Jackson Auto \& Supply Co., 237 Miss. 660, 115 So. $2 d 309$ (1960). For a discussion of how far this new approach may go, see Symposium, Transient Jurisdiction-Remnant of Pennoyer v. Neff: A Round Table, 9 J. PUB. L. 281 (1960).

11 A few souls, not as timid as others, have suggested that the United States Supreme Court might abandon or actually has abandoned the first basis-physical power-the specter of the sheriff boarding the airplane, summons in hand. Professor Ehrenzweig is the chief proponent of this view. See Ehrenzweig, CoNflict of LAws. PART ONE: JURISDICTION AND JUDGMENTS $\S 30$ (1959) [hereinafter cited as EHRENzWEIG]. See also Schlesinger, Methods of Progress in Conflict of Laws, Some Comments on Ehrenzweig's Treatment of "Transient" Jurisdiction, 9 J. PUB. L. 313 (1960). 
The later conflicts texts reiterate the traditional learning that in a free society the Constitution does not prohibit, either prior to or after suit is filed, a defendant from agreeing to have a court hear the plaintiff's case and to allow such hearing without any notice to the defendant.12 The tentative second edition of the Restatement of Conflict of Laws sees no problem in consent jurisdiction. ${ }^{13}$

The text writers point out that there are some problems, e.g., determining the extent of the consent, but such problems are treated as minor, 14 although most casebooks on conflict of laws include one hard cognovit case. 15

Although these cases always seemed intriguing, the text writers were comforting. Two recent articles, however, have prompted this inquiry. Professor Paulsen argued in the Iowa Law Review16 that an F2 court, in a consent case, should treat Fl's ${ }^{17}$ choice of law rule as jurisdictional when the plaintiff asked F2 to give full faith and credit 18 to the F1 judgment. A comment on state court jurisdiction appearing in the Harvard Law Review was the second article. ${ }^{19}$ There the editors of the Review, in their excellent student symposium on the current status of constitutional jurisdiction in state courts, without the citation of precedent, ${ }^{20}$ said of cognovit clauses: "The waiver of notice provision, moreover, may render enforcement of the notes unconstitutional."21

12 EkrReNZWEig § 27, at 89; Goodrich, Confuict of Laws \$ 73, at 196 (3d ed. 1949) [hereinafter cited as GOODRICH]; LEFLAR, THE LAW OF CONFLICT OF LAWS, \&29 (1959) [hereinafter cited as LefLAR]; STUMBerg, PRINCTPLES OF CONFLICT OF LAWS 81 (2d ed. 1951) [hereinafter cited as STUMBERG].

13 Restatement (SECOND), CoNflict of Laws \$ 81 (Tent. Draft No. 3, 1950): "A state has judicial jurisdiction over an individual who has consented to the exercise of such jurisdiction within limitations determined by the scope of the consent." See also comments d, $h$, and $k$. The lack of notice does not bother the RESTATEMENT either. See $\$ 75$, comment $g$.

14 See note 12 supra.

15 The case of Hazel v, Jacobs, 78 N.J.L. 459, 75 Atl. 903 (1910), appears in LORENzzEN, Confuicts of LAws 40 (6th ed. 1951), and StuMBerg, CONFLICT OF LAws 19 (1950). The case of Egley v. Bennett \& Co., 196 Ind. 50, 145 N.E. 830 (1924), appears in ChEATHAM, GOODRICH, GRISWOLD \& REESE, CONFICT OF LAWS 111 (4th ed. 1957). The case of Jones v. Turner, 249 Mich. 403, 228 N.W. 796 (1930), appears in HARPER, TAINTOR, CARNAHAN \& Brown, CONFICT OF LAWS 672 (1950).

16 Paulsen, Enforcing the Money Judgment of a Sister State, 42 IowA L. Rev. 202, 209-12 (1957).

17 " $F 1$ " is the traditional conflicts shorthand referring to the state where the original judgment was entered. "F2" refers to the state where the plaintiff seeks to enforce his judgment.

18 See U.S. ConsT. art. IV, $\S 1$ : "Full Faith and Credit shall be given in each State to the public Acts, Records and judicial Proceedings of every other State. And the Congress may by general Laws prescribe the Manner in which such Acts, Records and Proceedings shall be proved, and the Effect thereof." Congress has implemented this clause. 62 Stat. 947 (1948), 28 U.S.C. § 1738 (1958).

19 Developments in the Law-State Court Jurisdiction, 73 HARv. L. REv. 909 (1960).

20 Surely an unusual practice at the Harvard Law Review.

21 Developments in the Law, supra note 19, at 944. 
There was also a nagging suspicion that while consent raised interesting theoretical arguments on due process jurisdiction, due process notice, and the requirements of full faith and credit, it might not present much of a practical problem. With the extensive statutory restriction on cognovits, 22 it was possible that consent, as typified by cognovit clauses, was not being used to any degree by the finance industry.

Further, although consent as a basis of jurisdiction is usually discussed in the abstract as though the law dealt with two large and relatively equal parties, undoubtedly a huge percentage of such consents appear as a cognovit clause in a note given by a borrower to a bank or finance company. If true, the use of and commercial need for cognovit jurisdiction was relevant to any determination of fair play and substantial justice. Certainly, industrial knowledge and experience would be indispensible for any meaningful discussion of the existing doctrine or of proposed improvements. Therefore, industry attorneys and executives who had day to day experience with the use of cognovit clauses were contacted by letter in the hope of supplying a few answers.

This article, then, will report on the information received from the industry on the use of and attitude toward cognovits; will quickly review the state of the existing law, both case and statutory; and finally will speculate on the "proper" application of due process and full faith and credit to cognovits.

\section{THE INSTITUTIONAL APPROACH}

Lawyers and executives in the finance industry were questioned, by letter, on the use of cognovit clauses, the attitude of industry decision makers toward their propriety, and the techniques of industry attorneys in handling the conflict problems. Although the lawyers and executives contacted were in no sense a statistical sample, comments were elicited from knowledgeable counsel and executives of a broad range of large and medium-sized sales-finance companies, small loan companies, banks and trade associations. ${ }^{23}$ Names were

22 See the section on Traditional Wisdom infra.

23 Letters were received from the following: Mr. Clifford R. Schuman, Assistant to the General Counsel, Universal C.I.T. Credit Corporation, New York, N.Y.; Mr. Warren Van Norman, Corporate Counsel and Public Relations Director, Securities Acceptance Corporation, Omaha, Nebraska; Mr. R. K. Doughty, Legal Analysis Department, General Motors Acceptance Corporation, New York, N.Y.; Mr. W. F. Robinson, General Counsel, Pacific Finance Corporation, Los Angeles, California; Mr. L. J. Wynne, Counsel, General Acceptance Corporation, Allentown, Pennsylvania; Mr. George W. Omacht, Vice President and Senior Counsel, and Mr. Paul R. Moo, General Counsel, Associates Investment Company, South Bend, Indiana; Mr. Floyd E. Britton and Mr. Roger S. Barrett, Hubachek \& Kelly, Attorneys at Law, Chicago, Illinois (Attorneys for Household Finance Corporation); Mr. John E. Peterson, Attorney, Vice President and Secretary, Dial Finance Company, Des Moines, Iowa; Mr. Max M. Ainsworth, Chairman of the Board and Chief Executive Officer, Industrial Finance and Thrift Corporation, New Orleans, Louisiana; Mr. L. J. Holroyd, Assistant General Counsel, State Loan and Finance Corporation, Washington, D.C.; Mr. J. Leonard Smith, Jr., of Reed, Smith, Shaw \& McClay, Attorneys at Law, Pittsburgh, Pennsylvania (Counsel for Mellon National Bank and Trust Company, Pittsburgh, Penn- 
obtained by a use of a non-scientific, but effective source. Outside information gave the names of W. F. Robinson, General Counsel of Pacific Finance Corporation, and of John D. Masterson, Secretary of the American Finance Conference, Inc. They were asked to, and did, supply other names. A sort of chain letter process resulted, showing extensive duplication, until time forced a halt. Those answering24 displayed a wide knowledge not only of their particular clients' practices, but of their segment of the industry as a whole. The field was reasonably well covered. Information concerning the use of cognovits and court practices in Chicago, Illinois, were compiled for the author by Richard R. Elledge, a student at the University of Chicago Law School.25

The various replies indicate a complex combination both of inclusion, in standard company forms, of cognovit clauses and of their use when included. Apparently the determinants of the variables include geography (law, myth, and custom of a particular state); the felt or unfelt pressures of competition; the desired corporate image (public relations and industrial relations); the concept as to the role of the legal counsel held by the legal staff; and the availability of other security devices (law and type of loans).

But few generalizations are possible. Example must suffice. For those companies that include and use cognovits, Illinois, Pennsylvania, and Ohio are by far the most popular states and produce the overwhelming bulk of cognovit judgments taken in the United States. ${ }^{26}$ All three states currently provide for cognovits 27 and the small loan or retail sales acts do not prohibit their use. 28

sylvania); S. Knox Hunter, Assistant Secretary, Pittsburgh National Bank, Pittsburgh, Pennsylvania; Mr. Stanley L. Lind, Attorney at Law, Kansas City, Kansas (Counsel and Executive Secretary of the Kansas Consumer Finance Association); Paul L. Selby, Executive Vice President, National Consumer Finance Association, Washington, D.C.; and Mr. John D. Masterson, Secretary, American Finance Conference, Inc., Chicago, Illinois. These letters are on file at the University of Kansas Law School Library. Dr. N. R. Neifeld, Economist, formerly with Beneficial Management Corporation, was kind enough to give me some general information concerning the finance industry and to suggest various sources of information.

24 Not everyone did. The following failed to answer the letter: Thomas McCausland and J. Francis Ireton of Muecke, Mules \& Ireton representing Commercial Credit Corp.; Joseph Louis of Family Finance Corp.; Colonel Edger Higgins of Beneficial Finance Corp.; R. Bruce Snow of American Investment; and Frank Csar of General Finance Corp.

${ }^{25} \mathrm{His}$ report is also on file at the University of Kansas Law School Library. Previously published material gave additional information on industry practices. Pennsylvania practice in 1954 is reported in Note, Confessions of Judgments, 102 U. PA. L. REv. 524 (1954). For earlier practices in Ohio, see Hunter, The Warrant of Attorney to Confess Judgment, 8 Onto ST. L.J. 1 (1941).

${ }^{26}$ All informants commenting agree. None deny. For the same conclusion, see Note, 102 U. PA. L. REV. 524 (1954). In most of the cases where enforcement is sought in F2, the original judgment was taken in Illinois, Pennsylvania or Ohio.

27 Ill. Rev. Stat. ch. 110, §50 (4) (1959); OHio Rev. CODE ANN. § 2323.13 (Baldwin 1960); PA. Stat. ANN. tit. 12, \$739 (Purdon 1960).

28 The retail sales finance act of Illinois specifically allows their use in a retail sales finance contract, but it may be enforced only after default. See note 113 infra. 
Time did not permit exploration on why these three states should be unique. An attempt was made in Illinois during the Spring of 1961 to tighten up on credit practices and to prohibit cognovits. 29 The general prohibition apparently failed although the legislature did restrict cognovit judgment as a basis for garnishment. 30 Yet Ohio and Pennsylvania seem content. 31 Undoubtedly early history and long standing custom, lobbying skill and the folklore as to the proper relationship of debtor and creditor ${ }^{32}$ all play a role.

To what extent these companies included a cognovit clause generally, or in specific types of loans, in other states remains vague. Several informants said that as to particular types or on all loans their company included cognovits: "[ $\mathrm{n} n$ all instances where they are legal." 33 However, the only other states specifically mentioned by informants were Louisiana, where two companies include cognovits for local procedural reasons, even though judgments are not taken under them, ${ }^{34}$ and Wisconsin, where one company mentioned using cognovits in loans under the discount loan law, but not under the small loan

29 George Omacht inclosed a copy of the Chicago Sun-Times, April 12, 1961, p. 16, col. 1, reporting that such a bill passed the Ilinois House.

30 The Illinois legislative session ended on June 30, 1961, with no general prohibition being reported. 3 CCH, CONDIT. ChAT. MORT. REP. I 28,903 (1961). The legisiature did add section 82 to the Garnishment Act (ILI. REV. STAT. ch. 62, \$82 (1961)), to provide, rather ambiguously, that before "seeking a deduction order" the confession judgment must be "confirmed" after a trial de novo. The statute provides that the plaintiff must make an attempt, at least, to give defendant a form of notice prior to the trial de novo. Ill. Laws 1961, p. -, H.B. No. 462, $\$ 12$ (June 19, 1961).

${ }^{31}$ Floyd E. Britton of Hubachek \& Kelly, counsel for Household Finance, states: "One hears of no complaints in that state [Pennsylvania] about abuses of confessions. In Ohio ... I recall no public outcry as is presently the case in Illinois."

32 Floyd Britton and Roger Barrett of Hubachek \& Kelly for Household Finance Corp. suggest that cognovits can only be evaluated in terms of other creditor remedies. Yet the available remedies vary among the three states and are not significantly different from many of the other $\mathbf{4 7}$ states that put more of a limitation on cognovits.

${ }^{33}$ L. J. Wynne for General Acceptance Corporation. Cliford R. Schuman for Universal C.I.T. reports, as.to their consumer loan operation, that: "[A] confession of judgment is included ... wherever the general law of the particular jurisdiction permits it and the small loans law, if any, in that jurisdiction does not prohibit it." W. Omacht for Associates Investment Company says: "II]n states with a confession of judgment statute the clause is a part of the boiler-plate of every obligation."

34 Clifford Schuman reporting for Universal C.I.T. states that: "In Louisiana, the confession is rarely, if ever, used. It is included to convince a local judge that executory process under Louisiana law should be permitted." Max Ainsworth reporting for Industrial Finance and Thrift Corporation, doing business in eleven southern states, wrote that only in Louisiana does his company still retain the cognovit clause. He said: "The only reason the cognovit clause has been left in the Louisiana chattel mortgage form is for the purpose of proceeding 'via executiva' if it were to become necessary, and frankly, I cannot recall an occasion where it was necessary to use this proceeding in the last few years. ... It is effective only where a loan is made above the small loan limit of $\$ 300 \ldots$... See note 92 infra for Louisiana law. 
act.35 One informant mentioned that cognovits were used in Colorado, although his company did not use them. ${ }^{36}$

Many companies, even though doing business in the popular states, Illinois, Pennsylvania, and Ohio, refuse to include a cognovit at all. The industry is split, and from the tone of the letters, bitterly so. Apart from the proffered explanations, the facts show that those companies primarily engaged in sales financing, as distinct from small loans, tend to omit them. 37 General Motors Acceptance Corporation and apparently Pacific Finance Corporation both deny inclusion. ${ }^{38}$ Securities Acceptance Corporation denies inclusion, but IIlinois, Pennsylvania, and Ohio are not among the fifteen states in which it does business. 39 Universal C.I.T., although doing business in all fifty states, includes a cognovit clause in its form lien documents in only four statesIllinois, Ohio, Pennsylvania, and Louisiana. 40 But the cognovit clause is used only when necessary and is not favored. 41

The reports from the small loan companies show greater inclusion, but

35 Roger S. Barrett reporting for Household Finance Corporation.

36 Warren Van Norman reporting for Securities Acceptance Corp. L. J. Wynne reporting for General Acceptance mentioned Idaho, Maryland and Virginia, but implied that cognovits were not used by his company since they were prohibited by the small loan law (all three states) or by the sales finance act (Maryland).

37 Information was specifically requested as to the types of loans made. The answers show that traditionally there was a major division in the finance industry-those financing retail sales, primarily automobiles, who are now members of the American Finance Conference, Inc., and those engaged in direct loans of small amounts, normally under small loan laws, who are now members of the National Consumer Finance Association. Today, however, those selling money have felt the need, along with the rest of American industry, to diversify their product. Most of the informants report that while primarily engaged in either sales financing or small loans, they now engage in or are entering the other field, although for some it is still in an experimental stage. Many of these companies also have a çommercial division which apparently competes with commercial banks on large loans. Floor plan financing is also a quite typical activity.

33 R. K. Doughty for GMAC reports: "General Motors Acceptance Corporation has never, so far as I can learn, employed cognovit clauses." W. F. Robinson for Pacific Finance Corporation did not specifically deny inclusion by Pacific Finance but stated: "Even in those states where confession of judgment clauses are permitted, many companies will not use them or enforce them, principally because of the possible adverse effect upon public relations." The whole letter invokes distaste for "practices which are likely to be viewed by the public as unconscionable or unfair."

39 Warren Van Norman reports: "Securities Acceptance Corporation ... does not use such a clause in any such instrument and, as near as I have been able to learn, never has."

40 Cliford Schuman reports that judgments are not taken in Louisiana. See note 34 supra.

41 Schuman reports: "[Y]ou will appreciate how infrequently we introduce a confession of judgment in retail installment motor vehicle business. It has never been looked upon as a desirable method of enforcing liability generally, even apart from state laws which may prohibit it or create procedural difficulties in enforcing it. This policy has been constant and of long standing here." 
statements questioning, pro and con, the wisdom of cognovits become more frequent. Again, ignoring motives for the moment, the facts show that General Acceptance Corporation and Associates Investment Company include cognovits wherever legal.42 Household Finance, doing business in forty-five states, includes them only in Illinois, Pennsylvania, and Ohio and on discount loans in Wisconsin. ${ }^{43}$ Others never or only in a limited manner print cognovits in their contracts. Although doing business in Illinois and Pennsylvania 44 and twentyone other states, Dial Finance Company never includes them. 45 Industrial Finance and Thrift, doing business in eleven Southern states, ignores them except for technical reasons in Louisiana. 46 Doing business in Illinois and Ohio as well as twenty-seven other states, State Loan and Finance Corporation includes cognovits only in Pennsylvania. 47 In Kansas, a state where there are only procedural limitations on the use of cognovits, Stanley Lind, Counsel and Executive Secretary of the Kansas Consumer Finance Association, advises that to his knowledge a cognovit clause is not included by any chain or independent loan company, sales finance company or bank in Kansas. 48

But even inclusion in the credit instrument by those companies does not necessarily imply the use of the clause to take judgment. As mentioned above, 49 the inclusion of the clause in notes in Louisiana is for technical reasons only, not for the taking of judgment. Information was sought as to when and under what conditions judgments were taken under the clause. Many an-

42 L. J. Wynne for General Acceptance reports: "Our company uses notes containing a cognovit clause in all instances where they are legal." However, he specifically talks in terms of Illinois, Pennsylvania and Ohio. Paul Moo reporting for Associates Investment Company states: "[G]enerally . . . our company uses judgment notes or contracts containing cognovit clauses wherever legally permissible." George Omacht of the same company speaking generally said: "[Tn states with a confession of judgment statute, the clause is a part of the boiler-plate of every obligation. It is in all obligations taken by banks and other lending institutions whether the obligation is for one hundred dollars or a million."

In contrast to Universal C.I.T.'s limited use of cognovits in sales financing, Clifford Schuman reports that: "[]] consumer loans, confession of judgment is included in the pertinent obligation wherever the general law of the particular jurisdiction permits it and the small loans law, if any ... does not prohibit it."

43 Letter from Floyd Britton of Hubachek \& Kelly.

4 But not Ohio.

45 Letter from John Peterson.

16 Letter from Max Ainsworth. He said that cognovits were taken out of loan instruments, except in Louisiana, ten years ago. See note 34 supra for a discussion of the Louisiana problem.

47 Letter from L. J. Holroyd.

48 "To my knowledge, this type of clause is not used by any finance company in Kansas. I would be greatly surprised to learn that they are used by any of the banks in Kansas." Letter from Stanley Lind.

49 See note 34 suyra. 
swers were vague, but most implied that on small consumer loans, judgments were rare. Actually judgments were more frequent on the larger commercial loans. 50

However, Elledgesi reports that in the Municipal Court of Chicago, which handles the majority of confession cases and which hears more cases per year than all other courts in the State of Illinois combined, there were 45,402 suits on confession of judgment out of a total of 193,191 suits filed in 1960. There are no statistics available for the Circuit Court of Cook County or the Superior Court of Cook County, but estimates give each ten to fifteen confession judgments a week or a minimum total of 1,000 more cases a year. ${ }^{52}$ Surely a large volume of cognovit judgments!

What reasons are offered by these attorneys for the inclusion or non-inclusion of cognovit clauses? The most obvious factor is the prohibiting or procedural limitation statutes of the several states. Most informants commented on the many prohibitions found in state laws as an overall restricting factor on their use. These restrictions also result in a decision to refrain from using

so L. J. Wynne replied for General Acceptance Corporation: "On an overall basis, relatively few judgments are ever entered except on the commercial loans. In Pennsylvania judgment would be entered on a personal loan after default (although this is not a prerequisite in Pennsylvania) but only if the particular borrower is known to have personal or real property upon which a lien could be created. ... On the Sales Finance accounts in Pennsylvania we look first to the security and only enter judgment under the same circumstances as . . . personal loans. On commercial loans we do enter judgment immediately for the purpose of creating a lien on real property. ... [Outside Pennsylvania] we confess judgment upon default at any time it appears practical to do so and, of course, it is legal to do so."

Paul Moo reporting for Associates Investment Company said: "You next inquire whether judgments are entered under such contracts and notes and, of course, the answrer is definitely yes."

Clifford Schuman reporting for Universal C.I.T. replied: "[T] is utilized wherever the conditions in the particular case indicate it is advisable or necessary. ... [N]o specific rule of thumb is possible. From the above, you will appreciate how infrequently we introduce a confession of judgment in retail installment motor vehicle business."

L. J. Holroyd replied for State Loan and Finance rorp.: "We use Comovit clauses in notes only in ... Pennsylvania. ... From time to time with delinquent accounts judgments are entered. This is done at the discretion of the operating people, if they think it will assist them in collection."

Apparently in Pennsylvania a larger percentage of judgments are eatered since judgments are taken before default to be used in lieu of a mortgage. For the peculiarities of Pennsylvania practice, see Note, 102 U. PA. L. REV. 524 (1954). Both J. Leonard Smith, Jr., of Reed, Smith, Shaw \& McClay, reporting for The Mellon National Bank of Pittsburgh, Pennsylvania and S. Knox Hunter reporting for the Pittsburgh National Bank state that judgments are taken on cognovits extensively and particularly on real estate loans.

51 See note 25 supra and accompanying text.

52 In Hunter, The Warrant of Attorney to Confess Judgment, 8 Omo Sr. L. J. 1 (1941), the author argued that there should be greater use of cognovits in Ohio and other states. However, he reports that in the Franklin County Common Pleas Court: "In a period of approximately eighteen months from August 1937 to February 1939 a total of 3510 civil cases were filed. 500 cases or 14.2 per cent . . . were those involving cognovit notes." Id. at 14 . 
cognovits in states where they are legal. Apparently the companies desire to keep their practice uniform. 53

The major split seems to revolve around the view held by the company as to the public reaction to cognovits and the inherent "fairness" of a judgment procedure that does not provide for notice. Typical negative comments include: " $\mathrm{My}$ feeling is that the small advantage of a cognovit clause is overwhelmingly outweighed by the possible ill will that would be created toward the customers, opposing lawyers, judges, and the public in general."' 54 "Even in those states where confession of judgment clauses are permitted, many companies will not use them or enforce them, principally because of the possible adverse effect upon public relations." 55 "Top management . . . considers that a debtor ... should not by a device such as this be denied his 'day in court.' Quite obviously there could be an adverse reaction by the courts and the public at large against the finance industry if widespread use were made of the "cognovit clause' device." 56 Others in the field also express a negative attitude, 57 and even users of the clause admit that inequities may exist. 58 The attitude of the trade associations is mostly unknown. ${ }^{9}$ However, Paul L. Selby, Executive Vice-President of the National Consumer Finance Association said: "I feel very strongly that the cognovit clause should not be used in the note contracts for consumer installments cash loans made under the Small Loan Act."

53 John Peterson reporting for Dial Finance Company said: "We do not use ... due to the fact that most of the small loan laws under which we operate have a prohibition against such notes." Dial operates in Illinois and Pennsylvania. Warren Van Norman reporting for Securities Acceptance Corporation said that there were two reasons for not using cognovits. One was public relations discussed infra. The other was that Nebraska prohibited cognovits when the company was first organized. Although it now does business in fifteen ststes, "most of these expressly prohibit such clauses. ..."

54 Max Ainsworth for Industrial Finance and Thrift.

55 W. F. Robinson for Pacific Finance Corporation.

56 Warren Van Norman for Securities Acceptance Corporation.

57 The concept that, apart from "public relations," the use of such a clause is inherently unfair is well expressed by Stanley Lind for the Kansas Consumer Finance Association. Having drawn mpst of the forms for use by Kansas companies, he comments that such clauses could be used in Kansas, but adds: "[T]he reason I do not use this clause in notes, mortgages and contracts . . . is that I do not consider such a clause fair to the borrower nor consistent with the concept of notice as embodied in our process statutes."

Others mentioning adverse public relations include R. K. Doughty of General Motors Acceptance Corporation and Clifford Schuman of Universal C.I.T.

s8 George W. Omacht for Associates Investment Co. said: "Some hardship cases appear under the [cognovit] system, but I think an equal number of hardship cases appear under the summons and judgment after hearing plan." Floyd E. Britton of Hubachek \& Kelly for HFC said: "There is one class of claims, however, where confessions may lean too heavily in favor of creditors. In actions to recover what is generally described as deficiencies ... the amount actually due often, if not generally, depends on ex parte action by the creditor. Confessions in such actions are subject to abuses."

59 John Masterson, Secretary, American Finance Conference did not express an opinion. Other associations were not contacted. 
Most users of cognovits are quick and forceful in their defense. They claim little or no adverse public reaction to such clauses, or at least that it is not a problem. Typical comments include: "[T] here has been no public reluctance to execute judgment obligations. ... Debtors in states permitting judgment notes are apparently accustomed to giving that type of obligation. ... [W] use them wherever legally permissible, have had no adverse public reaction to their use and feel that they are a legitimate and proper collection device." 60 "We consider no other factors in determining whether a cognovit clause is included in the note beyond its legality.... On personal loans and sales finance accounts, we have no recollection whatsoever of any borrower or purchasers refusing to sign such a note. The good will of the borrower or purchaser has never been a factor." 61 "[V]ery few borrowers are alarmed by the presence of a warrent of attorney.... Accordingly, the practice seems to be general in Pennsylvania."62

One defender pointed out that it is unfair to value the cognovit clause in isolation. Other creditors' remedies are as important. Floyd Britton of Hubacheck \& Kelly for Household Finance Company remarked: "[Legislatures should] consider the problem as one involving the aggregate of legal collection remedies prevailing in the particular jurisdiction, the job being to achieve some kind of balance between the interests-the real interests-of all parties and the public. It surely is not an easy solution and much depends on custom and tradition in each jurisdiction."63

Mr. George Omacht for Associates Investment Company argued that the national policy promoting the sale of consumer goods had to be balanced against debtor protection. If good collection procedures are available, loans will be made to weaker borrowers. He remarked: "I do not know the answer to this problem of public policy. Finance companies and consumer lenders can fit their credit policy to either policy the state chooses."

Several defenders counter-attack the basic claim of the non-users that lack of notice prior to suit is inherently unfair. The argument is twofold. (1) "A confession clause permits the lender to obtain quickly and cheaply a lien against the debtor, where generally the only real defense is unwillingness or

60 Paul Moo for Associates Investment Company.

61 L. J. Wynne for General Acceptance Corporation.

$62 \mathrm{~J}$. Leonard Smith, Jr., of Reed, Smith, Shaw \& McClay for Mellon National Bank. L. J. Holroyd for State Loan and Finance Corp. added: "[It] is the general practice in the trade, so there is no adverse public or customer relations effect."

63 Roger Barrett of Hubachek \& Kelly echoed these statements. Earlier Mr. Britton gives an example of the need of looking at total remedies. He said: "[T]n Illinois where a power of attorney ... is common, a garnishment procedure may proceed immediately on entry of judgment. In Wisconsin where... under the small loan law, judgments by confession are prohibited, gamishment procedure may proceed prior to judgment. It is doubtful therefore whether there is any real or practical difference. . . . The guy's wages have been garnished without prior notice in either case!" 
inability to pay." 64 (2) "[T]he judges freely grant motions to vacate judgments by confession. ... The judges seem to rely on the theory that the defendant is entitled to his day in court, and if the motion alleges any defense, regardless of how weak it may be ... he generally grants the motion and sets the case for trial."65

To what extent consumer loan or installment buyer defendants, when informed of a judgment through execution or garnishment, employ a lawyer to "open the judgment" is unknown. Mr. Elledge66 reports: "There are no statistics on the frequency of motions to open or vacate judgments, but Judge McNamara67 and his bailiff estimate that ten to twelve motions are entertained in an average week." 68 How many improper judgments are taken is unknown. However, Mr. Elledge included in his findings five reports of John King, Special Commissioner of the Municipal Court, 69 covering the period of July 25,1960 , to December 15,1960 . A typical early report shows that from August 5 to August 18 there were 1,774 judgments filed. Commissioner King and his staff rejected 377 for a wide variety of errors including "No confession clause in the note"; "Statute of limitation"; and "Confession against a single person on a joint note."70

The system seems to invite abuse. According to Elledge, printed forms are used. A clerk in the judge's office supposedly checks the papers. He then initials the statement of claim, rubber stamps "his" judge's signature, and enters the name of the case and the amount of the judgment in the judgment book. The pages of this book are signed by the judge daily. With better than 45,000

${ }^{64}$ S. Knox Hunter for Pittsburgh National Bank.

${ }^{65} \mathrm{George}$ Omacht for Associates Investment $\mathrm{Co}$. Both these arguments were also made by Floyd Britton of Hubachek \& Kelly for Household Finance Company and J. Leonard Smith, Jr., of Reed, Smith, Shaw \& McClay for Mellon National Bank. See note 126 infra, for cases discussing the right to open a confession judgment.

66 See note 25 supra and accompanying text.

67 Judge of the Municipal Court of Chicago.

68 Elledge earlier reported an average of 875 confession judgments per week in the Municipal Court. According to Commissioner King, appointed by Mayor Daley to investigate credit practices in the Municipal Court, "No motion to vacate with any merit at all has ever been turned down."

69 King was appointed by Mayor Daley of Chicago, Mlinois, to investigate credit practices in Chicago Municipal Court. The reports were sent to the Chief Justice of the Municipal Court.

70 Other reasons listed were that: 2 . The note had not matured; 3. Variance between named defendant and signature on note; 4. Excessive attorney's fees; $S$. Affidavits not signed; 6. Rubber stamps used for signature; 7. Excessive interest; 8. Principal not properly named; 9 . Affidavits not properly made; 10 . Notes with no provision for attorney fees. Later reports show fewer rejects. Undoubtedly, creditors realized Commissioner King was checking.

Many comments on individual cases appear in these reports and show a wide variety of abuses. There is some evidence that the rejects tend to center in certain companies. Happily none of the companies who participated in the author's survey appear on Commissioner King's list. 
judgments a year, it is not surprising that Commissioner King found many errors. 71

One defense raised by two or three users centered on the problem of court congestion in our large cities. Confession judgments now avoid the delay. Notice and a hearing would greatly increase the congestion, they argue, and would necessitate an increased number of judges and process servers. This may be a very real, practical problem to any plaintiff. But delay, or the expense in increasing the number of judges, is hardly adequate reason to continue a practice if it is found to be unfair and unjust.

Problems of unfairness and public relations are not the only reason for non-use. The economics of the trade play an important role. As pointed out by $R$. K. Doughty, 72 finance companies doing business on a recourse basis with dealers are not faced with the same losses as are banks and small loan companies. This may partially explain why finance companies tend to make less use of the cognovit clause.73 Certainly many of the users expressed the economic need for such a clause. The clause, they argued, provided a quick and efficient method of obtaining judgment after default.74

A few other suggestions as to factors determining use or non-use are worth quoting. L. J. Holroyd75 mentions the importance of competition. His company uses the cognovits only in Pennsylvania. He said: "I would say it is the practice of the trade which determines whether or not we would use a cognovit clause. ... [W]e, as a company, would not use it unless the trade generally followed this practice."76 The pressure of competition may make it difficult for a company to resist. R. K. Doughty reporting for General Motors Acceptance Corporation, a company that does not use cognovits, remarked in passing: "One further point may be of some assistance. ... [O]ur Pennsylvania managers have quite often raised the question as to why we can't follow banking and other finance company practices by incorporating cognovit clauses in our contracts." 77

71 Professor Hunter does not purport to examine abuses. Hunter, The Warrant of Attorney to Confess Judgment, 8 OHIO ST. L.J. 1, 15 (1941). However, he found that in only 26 out of 500 cases did the defendant attempt to have it set aside and in only two cases was a judgment ultimately entered for the defendant. (In five cases the parties settled.) The fact that courts will freely and almost automatically open up a confession judgment hardly shows that the system works fairly. Rather it indicates that trial court judges feel that the system is inherently subject to abuse.

72 Reporting for General Motors Acceptance Corporation.

73 See note 37 supra and accompanying text.

$74 \mathrm{~L}$. J. Wynne for General Acceptance Corporation points out that when public relations is not a factor, the legal staff encourages increased use.

75 Reporting for State Loan and Finance Corporation.

76 Although State Loan does business in Illinois and Ohio, it does not use the cognovit clause in those states.

77 Mr. Doughty gives no answer in the letter, but presumably the general policy against use is strong enough to overcome the managers' objections. 
Although many users suggest the efficacy of the clause, Max Ainsworth of Industrial Finance and Thrift pointed out that ten years ago he removed the cognovit clause from its credit instruments because they were not needed. $\mathrm{He}$ added: "I doubt if any office of our entire system or the local attorney for each office has had an occasion whereby a cognovit clause would have been of any great assistance. At least, I have had no complaints."

One final point is of significance. Since the "adhesive" nature of a contract is an important determinant in conflict of laws, 78 the informants were asked about objections from borrowers to the inclusion of a cognovit clause. Users were unanimous in replying that the small borrower never objected. Several mentioned that the borrower was conditioned to cognovits. It was customary. 79 However, many raised the point that they made large commercial loans which included a cognovit clause. "Confession of judgment clauses are not limited, in the least, to consumer obligations." 80 Although S. Knox Hunter for the Pittsburgh National Bank implied that "out of state borrowers" and "corporate borrowers" may object, 81 L. J. Wynne for General Acceptance Corporation and Paul Moo for Associates Investment Company both state that as a matter of practice they insist that a cognovit clause be included in the large loan, despite the borrower's objection. As a practical matter, it might seem that all contracts between institutional lenders and borrowers are to be classified as adhesion contracts.

Probably the most surprising result of the inquiry was the lack of interest in the conflict of laws aspects of cognovits. Several specific questions were asked and while other questions were answered in detail, conflict questions were normally ignored. The few responses indicated that either the companies do not engage in practices that raise conflict issues or else the legal problems are not acute. For instance, one attorney remarked: "[Y]ou indicate in your first paragraph that your article will discuss mainly judgments by confession. Assuming validity in the state where the contract was made and in the state of the forum, FF\&C comes into play and some interesting legal and constitutional questions can arise. I had several a number of years ago, but at the moment do not recall the details." 82

Another attorney remarked that two questions had arisen, but the legal staff had not taken the time to resolve them. (1) Contract made in Florida,

78 Ehrenzweig, Adhesion Contracts in the Confict of Laws, 53 CoLuM. L. REv. 1072 (1952); RESTATEMENT (SECOND), CONFLICT of LAWS § 332a, comment $e$, at 20 (Tent. Draft No. 6, i960). For a full discussion of the nature and importance of "adhesion" contracts, see note 166 infra and accompanying text.

79 See note 60 supra and accompanying text.

${ }^{80}$ George Omacht for Associates Investment Company. He added: "Such loans are ssually in chunks of a million to five million."

81 He reports that some feel that their credit is such that they should not be required to xecute that type of note.

82 Lloyd Britton of Hubachek \& Kelly for Household Finance Corporation. 
which prohibits the clause, and later the defendant moved to Pennsylvania. May judgment be taken in Pennsylvania? (2) Contract signed in Florida by a resident there and mailed to Pennsylvania where it was accepted and the money disbursed. Judgment entered in Pennsylvania. May the judgment be enforced in Florida?83

The informants reported on three specific bits of information. L. J. Holroyd for State Loan and Finance Company remarked: "Incidentally, from a practical standpoint, we have had little difficulty proving our judgments in foreign jurisdictions based on a confessed judgment in Pennsylvania." Floyd Britton of Hubachek \& Kelly for Household Finance Corporation commented that: "Pennsylvania creditors sometimes confess judgment in Ohio where the defendant's employer may be served with garnishee process." He labels the taking of a judgment in a jurisdiction other than where the defendant resides or the cause of action arose, a "sharp practice." Paul Moo for Associates Investment Company, whose home office is in Indiana, explains that since Indiana prohibits cognovits, ${ }^{84}$ the company has the obligation payable at one of their offices in Illinois, Ohio or Pennsylvania. 85

The basic split in the industry on the justifications for use-public policy, fairness, need, competition, and custom, indicates, at best, a limited argument in favor of cognovit clauses in any type of credit instrument. The letters show that the industry itself would not object too strenuously to a complete abolition. 86 As one extensive user who strongly defended the practice said: "Finance companies and consumer lenders can fit this credit policy to either policy the state chooses." 87 Although the economic policy of the country favors credit buying, judgments without notice and opportunity to defend are not vital to that policy.

Information on the practices of the industry in using cognovits to take judgment in a state other than that of the domicile of the borrower is singularly lacking. While the letters indicate that the practice is not unknown and that it raises certain legal problems, it is not a current and bothersome one to industry lawyers. Nevertheless, the cases discussed in the next section indicate that the industry does try to enforce these judgments in a second state.

The industry is split, but generally negative. But how have American legislatures and courts traditionally responded to consent as found in a cognovit clause?

83 L. J. Wynne for General Acceptance.

84 IND. ANN. STAT. \$ 2-2906 (1946).

85 The letter is not clear as to whether this is true on all obligations or only those signed by Illinois, Ohio or Pennsylvania citizens.

86 Perhaps the industry would object on Pennsylvania real estate loans. There the cognovit is not a collection device, but a security interest substituting a judgment lien for a mortgage by taking judgment the day the money is loaned. See Note, 102 U. PA. L. REv. 524 (1954). The validity of this policy must be left to experts on mortgages and securities.

87 George Omacht for Associates Investment Company. 


\section{The Traditional Wisdom}

State legislatures have reacted to the problem of cognovit clauses in a wide variety of ways. Affirmatively there are only seven states having general statutes which specifically allow their use. 88 The legislatures of two states, Indiana, and New Mexico,89 not only declare them void, but make the execution of such a clause a misdemeanor. Thirteen other states merely declared such clauses void. 90

In the other twenty-seven states the status of cognovits is not as clear. Four states have no pertinent statutes.91 The remaining twenty-three place various procedural limitations on the confession of judgments generally, 92 which

88 Def. CODE ANN. tit. 10, § 2306 (1953); HawaII Rev. LAws \$229-3 (1955) (on notes not exceding \$1000.00); IrI. REv. STAT. ch. 110, § 50(4) (1959); OHO REv. CODE ANN. $\S 2323.13$ (Baldwin 1960); PA. Stat. ANN. tit. 12, § 739 (Supp. 1960); VA. Code ANN. $\S \S 8-355,8-356$ (1950); WIS. STAT. $\$ 270.69$ (1957).

A typical statute reads: "It shall be the duty of the prothonotary of any court of record, within this commonwealth, on the application of any person, being the original holder (or assignee of such holder) of a note ... in which judgment is confessed, or containing a warrant for an attomey at law, or other person, to confess judgment, to enter judgment against the person or persons who executed the same ...." PA. STAr. ANN. tit. 12, § 739 (Supp. 1960).

However, by court decision the use of a cognovit may be rendered difficult. See General Contract Purchase Corp. v. Max Keil Real Estate Co., 35 Del. (5 Harr.) 531, 170 Atl. 797 (Super. Ct. 1933) (limiting cognovits to notes under seal). Note also that several of these states prohibit confession clauses in particular types of loans. See note 112 infra and accompanying text.

89 IND. ANN. Stat. § 2-2906 (1946); N.M. Stat. ANN. §§ 21-9-16, 21-9-18 (1953).

90 Ala. CODE tit. 20, §16 (1958); Ariz. Rev. Stat. ANN. \$44-143 (1956); Fla. Stat. $\S 55.05$ (1959); GA. CODE $\$ 110-601$ (1933); KY. REV. STAT. ANN. $\S 372.140$ (1955); MASs. Gen. Laws ANN. ch. 231, §13a (1959); Mich. CoMP. LAws §622.3 (1948); Miss. Code ANN. \$1545 (1942); Mont. Rev. CODE ANN. \$13-811 (1947): N.J. Rev. Stat. § 2A: 16-9 (1951); TENn. Code AnN. \$25-201 (1955); Tex. Rev. Crv. Stat. AnN. art. 2224 (1959); VT. Stat. tit. 9, § 1480 (1947).

There is little uniformity in the language of the prohibiting statutes. The Massachusetts statute gives the basic approach. "Any stipulation in a . . . promissory note ... whereby a party thereto agrees to confess judgment in any action which may be brought thereon or authorizes or agrees to authorize another person to confess judgment as aforesaid shall be void ...." MASS. GEN. LAWS ANN. ch. 231, \& 13a (1959).

91 Colorado, Maine, New Hampshire, and Rhode Island.

92 ALASKa Comp. Laws ANN. §§ 55-9-31 to -34 (1949); ARK. STAT. ANN. §§ 29-301 to -303 (1948); Cal. Civ. Proc. Code §§ 1132-35; Conn. Gen. Stat. Rev. §§ 52-193 to -195 (1958); IDAHO CODE ANN. §§ 10-901 to -904 (1949); LOWA CODE §§ 676.1-.4 (1958); KAN. GEN. STAT. ANN. §§ 60-3111 to -3116 (1949); LA. CoNST. art. 7, § 44 (1921); Md. Ann. Code, Gen. R. Pr. and P. 645 (1957), MinN. Stat. §§ 548.22-.23 (1957); Mo. Rev. Stat. $\S \S 511.070-100$ (1949); Neb. Rev. Stat. $\$ \S 25-1309$ to -1312 (1956); Nev. Rev. Stat. $\S \S 17.090-110$ (1957); N.Y. Civ. Prac. ACt $\$ \S 540-545 ;$ N.C. Gen. Stat. $\S \S 1-247$ to -249 (1944); N.D. R. Civ. P. 68(c) (1960); OKLA. Stat. tit. 12, §§ 689-695 (1960); ORE. Rev. STAT. $\S \S 26.010-.030$ (1959); S.C. CoDE $\$ \S 10-1535$ to -1538 (1952); S.D. CODE $\$ \S 37-0301$ to -0303 (1939); UTAH R. CIV. P. 58A(e) (1953); WASH. REV. CODE $\$ \S 4.60 .010-070$ (1956); WYo. STAT. ANN. $\$ \S 1-309$ to -313 (1959). 
may93 or may not ${ }^{94}$ specifically provide for obtaining in personam jurisdiction through the use of a cognovit clause.

In those states with the latter type of statute and in the four states 95 lacking any statutory procedure for confessions, the courts are not in agreement as to the effect of the absence of a cognovit provision. The basic problem facing those courts is whether, without an authorizing statute, a cognovit clause can be used to obtain jurisdiction over the defendant apart from any restrictions on the procedure for confessing the judgment. 96 One view is that the lack of an authorizing statute is not fatal to obtaining jurisdiction through a cognovit clause. "Consent" and authorizing an attorney to make that consent for the defendant were used at common law to obtain jurisdiction. 97 Therefore, courts could argue that they need no statute authorizing this method of obtaining jurisdiction. Professor Leflar takes this view. 98 Decisions exist where the court apparently assumes this to be true, 99 even though it may require the general

93 There is some uniformity. For various types see, e.g., MrNN. STat. \$\$ 548.22-.23 (1957); MD. ANN. COdE, GFN. R. Pr. ANd P. 645 (1957); OKIA. Stat. tit. 12, §§ 689-95 (1960).

94 See e.g., Cat. Crv. Proc. Code $\$ \S 1132-1135$, as amended, Cal. Civ. Proc. Code §§ 1134-1135 (Supp. 1960); UTAH CODE ANN. \$ 78-22-3 (1953) allows confession of judgments. UTAH R. CIV. P. 58A(e) contains the limitations. Typically these statutes require the defendant to file an affidavit that the debt is due and owing after the suit is filed. "Before a judgment by confession shall be entered a statement in writing must be made and signed by the defendant and verified by his oath to the... effect... that the sum confessed therefor is justly due or to become due ...." S.C. CODE \& 10-1536 (1952).

95 See note 91 supra.

96 Today a cognovit actually purports to do two things: (1) authorize the court to assume in personam jurisdiction over the defendant and (2) authorize the court to render judgment on the merits for the amount confessed. See General Contract Purchase Corp. v. Max Keil Real Estate Co., 35 Del. (5 Harr.) 531, 170 Atl. 797 (Super. Ct. 1933), for a discussion of early common law practice.

97 For an extensive discussion of cognovits at common law, see First Nat'l Bank v. White, 220 Mo. 717, 120 S.W. 36 (1909). But see General Contract Purchase Corp. v. Max Keil Real Estate Co., supra note 96, denying common law authority. Early history is also discussed in Note, 102 U. PA. L. REv. 524 (1954).

98 LEFLAR $\$ 29$.

99 In Houpt v. Bohl, 71 Ark. 330, 75 S.W. 470 (1903), the court equates a cognovit with an appearance by the defendant and finds jurisdiction without any discussion of the problem. The court says that this is a judgment by consent and not a judgment by confession under the statute. The statute, ARK. STAT. ANN. § 29-301 to -303 (1948), appears to contain no restriction. It merely provides that any person may confess. In Hutchinson v. Palmer, 147 Ala. 517, 40 So. 339 (1906), the Alabama court found, without aid of statute, that a cognovit clause is as binding as service of process. See Monarch Refrigerating Co. v. Faulk, 228 Ala. 554, 155 So. 74 (1934), where the court pointed out that the Alabama statue prohibiting cognovits was enacted as a result of the Hutchinson case.

Of the four states having no general legislation, Colorado generally allows cognovits. Warren Van Norman for Securities Acceptance Corp. advises that cognovits are allowed in Colorado. See note 36 supra and accompanying text. Under CoLo. R. CIV. P. 4(i)(5) (1953), proof of service may be shown by waiver or written admission. No extensive search was 
confession statute to be strictly followed. 100 Judge Goodrich disagrees. In discussing judgment notes he says: "Whether a judgment may be entered in this way is, in the first instance, a matter of local procedure. The individual's authorization will not change local procedural statutes."101 Some courts deny102 or deny by implication a non-statutory procedure. 103

Therefore, cognovits can technically be used in any of these states which either expressly allow them by statute or allow them through the common law. But attorneys for the finance industry report ${ }^{104}$ that they are used sparingly since the various procedural limitations render cognovits ineffective as a speedy remedy. 105

In addition to the general limitation statutes, many state legislatures have specifically prohibited cognovit clauses in particular transactions. In 1915 the

made, but no case directly allowing cognovits was found. However, Metropolitan State Bank v. McNutt, 73 Col. 291, 215 Pac. 151 (1923), assumes their validity. In Mountain States Fixture Co. v. Daskalos, 61 N.M. 491, 303 P.2d 698 (1956), the parties assumed that the law of Colorado provided for cognovits. The Colorado trial court had entered judgment on a cognovit clause.

100 See, e.g., Barnes v. Hilton, 118 Cal. App. 2d 108, 257 P.2d 98 (1953).

101 GoOdRICH $\$ 73$, at 198.

102 In Hamilton v. Schoenberger, 47 Iowa 385 (1877), the court held that procedural statutes providing for judgments by confession are not merely cumulative, but abrogate the common law method. In General Purchase Corp. v. Max Keil Real Estate Co., 35 Del. 531, 170 Atl. 797 (Super. Ct. 1933) the court denied that at common law a judgment could be taken on a warrent of attorney without the plaintiff having first instituted an action. The court concluded that the statutory method, which required the note to be under seal, alone existed.

103 The Missouri Supreme Court in First Nat'l Bank v. White, 220 Mo. 717, 120 S.W. 36 (1909), took the view that, in the absence of a statute specifically allowing common law cognovits, such attempts at obtaining jurisdiction were against public policy and were an attempt to oust the jurisdiction of the court. However the court also suggested that assuming common law cognovits to be valid, nevertheless, the use of the clause could only be in conformity with the procedural limitations contained in the general confession of judgment statute. With the aid of a statute, Georgia arrived at the same result. Whitley v. Southern Wholesale Corp., 45 Ga. App. 445, 164 S.E. 903 (1932).

Oklahoma's statute, OKIA. STAT. tit. 12, $\$ 690$ (1960), allows an attorney to confess judgment; so it is of the second type. But in St. Louis-San Francisco Ry. v. Bayne, 170 Okla. 542, 40 P.2d 1104 (1935), the court held that unless the statutory limitations are complied with, a judgment without service of process on the defendant was void. Apparently a common law form could not exist.

In Wiley v. Neal, 24 Neb. 141, 37 N.W. 926 (1888), the Nebraska Supreme Court took the position that since the code required service of process in every case, a judgment entered on a cognovit clause was void. The plaintiff apparently did not argue the common law right.

104 See note 53 supra and accompanying text.

105 Although Maryland was listed as having procedural limitations, MD. ANN. CODE, GEN. R. PR. AND P. 645 (1957), the code specifically provides for cognovits and only requires that notice be given the defendant allowing him thirty days to show cause why the udgment should not be made final. The attorneys did not mention use in Maryland, but the tatute would seem to place only a minor restriction. 
Russell Sage Foundation sponsored a uniform small loan law. 106 Basically aimed at the loan shark's high interest rate, the uniform act contained a section prohibiting cognovit clauses. Enacted with variations and later amendments throughout the last forty years, some forty-five states have small loan acts with twenty-nine states ${ }^{107}$ prohibiting cogzovits.

A post World War II phenomenon is the many variants of the special acts controlling retail installment sales. 108 Although there is no "uniform" act, "legislative common law"109 is at work, and the acts generally follow a basic pattern. While aimed primarily at restricting unfilled-out contracts and usurious interest in the guise of finance charges, about one-third of the thirtyfive state statutes contain a section which prohibits the use of cognovit clauses. 110

As the states adopted one or both of these restrictive acts, the pattern on the prohibition of cognovits changed. The combinations and permutations are now wonderful to behold. Of the seven specifically allowing cognovits, 111 three

106 See Neifeld, Trends in CONSUMER Finance 1 (1954), for a discussion of the early history of the uniform small loan law.

107 AlA. CODE tit. 62, §248 (1958); ARIz. REv. STAT. ANN. \$ 6-629 (1956) (licensed money lender); Cal. Fin. Code § 24468; Conn. Gen. Stat. Rev. § 36-236 (1958); Fla. Stat. \$ 516.16 (1955); HawaII REv. Laws § 195-15 (1955); IDAHO CODE ANN. § 26-2013 (1949); IND. ANN. Stat. § 18-3003 (1950); IOWA CODE § 536.12 (1958); KY. REv. STAT. § 288.580 (Supp. 1961); LA. Rev. Stat. §6.585 (1950); ME. Rev. Stat. ANN. ch. 59, § 220 (1954); MD. ANN. CODE art. 58A, § 19 (1957); Mich. CoMP. LAws § 493.12 (1948); MinN. STAT. § 56.12 (1957); NEB. REv. STAT. § 8-430 (1950) (installment loan licensee), § 8-809 (1956) (banks on loans of $\$ 2,000.00$ or less); Nev. Rev. Stat. $\$ 675.350$ (1960); N.H. REv. STAT. ANN. § 399.28 (1955); N.J. REv. STat. § 17:10-15 (1937); N.Y. Banking LAWs § 353 (licensed lender's act); ORE. REV. STAT. \$ 725.050 (1955); R.I. GEN. LAws ANN. § 19-25-24 (1956); S.C. Code § 8-794.7 (1952); UTAH CODE ANN. \$ 7-10-14 (1953); VT. STAT. tit. 8, $\$ 9007$ (1947); VA. CODE ANN. §6-313 (1950); WASF. REv. CODE \$31.08.150 (1952); W. VA. CODE ch. 47, art. 7A, \$4653 (1955); WIs. STAT. \$214.14 (1957). Georgia formally prohibited confessions in small loans, GA. CODE § 25-315 (1933). In 1955 the Code was revised. The small loan law appears in GA. CODE ANN. \& 25-301 to -324 (1959). The prohibition against cognovits was logically omitted since they are prohibited generally by $G_{A}$. CODE § 110-601 (1933).

${ }^{108}$ Indiana, Wisconsin, and Michigan enacted statutes prior to World War II. Up to 1955 thirteen states had some sort of statute. However, it has been in the last five years that the state legislature (some twenty-one states) have gone into this area with a vengeance. Many acts cover motor vehicles only, e.g., MINN. STAT. \$168.011-.81 (1917)); ORE. REv, STAT. $\$ 83.510-990$ (Supp. 1957); but in recent years legislatures have included all sales.

109 Horack, The Common Law of Legislation, 23 IowA L. REv. 41 (1937).

110 The following ten states prohibit: Caz. Civ. Code $\S 1804.1 c ;$ Colo. Rev. Stat. ANN. \$ 13-16-6(1)(b) (1953) (motor vehicle retail sales); CONN. GEN. REv. STAT. \$ 42-88 (1958); Ky. REv. STAT. $\$ 190.100$ (1)(c) (Supp. 1961) (motor vehicle retail sales); MD. ANN. CODE art. 83, \& 130 (1957); MiNN. STAT. \$ 168.71(a)(2) (1957) (motor vehicle retail sales); N.J. Rev. Stat. \& 17:16B-6(3) (1937); N.Y. PERs. Prop. LAW \& 302(14); N.D. Rev. Code § 511312(13) (Supp. 1959); ORE. REV. STAT. \$ 83.670(1) (1957) (motor vehicle retail sales).

111 See note 88 supra. 
now prohibit their use by a small loan company, 112 while two specifically allow their use in a retail sales finance contract, but it may be enforced only after default.113

Strangely enough, of the sixteen states that generally prohibit cognovits, 114 seven state legislatures apparently unthinkingly outlawed cognovits in small loans, ${ }^{115}$ and two states prohibited cognovits in both small loans and in retail sales contracts. 116

Of the twenty-three states having procedural limitations, ${ }_{117}^{11}$ eight prohibit their use by small loan companies, 118 one in retail sales contracts only, ${ }^{119}$ and six in both areas. ${ }^{120}$

112 Hawail Rev. Laws § 195-15 (1955); Va. Code AnN. §6-313 (1950); Wis. Stat. §214.14 (1957).

113 ILL. REv. STAT. ch. 1211/2, § 234(11) (1959). On January 1, 1962, Hawaii's new retail sales act goes into effect. It follows the minois provisions. HAWAII REv. LAws § 201-11 (1 CCH, Condit. SAle-Chat. Mort. ReP. If 762 (June 19, 1961.)) The situation in Hawaii is unique. The general statute, HawaII REV. LAwS $\S 229-3$ (1955), allows cognovits up to $\$ 1,000.00$. The small loan statute prohibits them on $\$ 300.00$ or under. HawaII REv. LAws \$195-15 (1955). The new retail sales act, Hawan Rev. Laws \$201-11 (CCH, Condit. Sale-Chat. Mort. Rep. If 762 (June 19, 1961)), allows them!

In these seven states, Ohio, Delaware, and Pennsylvania adopted small loan laws; Ohio adopted a general retail sales act; and Pennsylvania, Virginia and Wisconsin adopted motor vehicle retail installments sales acts. All left out any clause prohibiting cognovits.

114 See notes 89 \& 90 supra.

115 Ala. Code tit. 62, § 248 (Supp. 1958); ARIz. Rev. Stat. AnN., § 6-629 (1956); Fla. STAT. § 516.16 (1959); IND. ANN. STAT. § 18-3003 (1950); Mich. COMP. LAwS § 493.12 (1948); VT. Stat. tit. 8, §9007 (1947); W. VA. CODE ANN. § 4653 (12) (1955).

116 N.J. STAT. ANN. § 17:16B-6(a)(3) (1950) (retail sales cơntracts), § 17:10-15 (1950) (small loans); KY. REv. STAT. $\S 288.580$ (Supp. 1961)(petty loan companies), $\S 190.100$ (Supp. 1961) (motor vehicle retail installment contracts).

Massachusetts, Mississippi, New Mexico, Tennessee, and Texas have adopted small loan legislation, but correctly assumed that the general statues would cover and therefore left out the anti-cognovit clause provision. Arizona, Florida, Indiana, Massachusetts, Michigan, Mississippi, Montana, New Mexico, Tennessee, and Texas currently omitted restrictions in their general or motor vehicle installment sales contract legislation.

117 See note 92 supra.

118 IDAHO CODE ANN. § 26-2013 (1949); IOWA CODE §536.12 (1958); LA. REv. Stat. $\S 6.585$ (1950): NeB. REv. STAT. $\$ 8-430$ (1956), § 8-809 (1956)(prohibits a bank from taking a confession of judgment clause on personal loans of $\$ 2,000$ or less); NEV. REV. STAT. $\S 675.350$ (1960); S.C. CODE § 8-794.7 (1952); UTAH CODE ANN. § 7-10-14 (1953); WasH. REv. CODE § 31.08 .150 (1952).

119 N.D. REv. CODE § 51.1302(13) (Supp. 1959).

320 CAL. CIv. CODE, $\S 1804.1 c$ (retail credit sales contracts), CAL. FIN. CODE $§ 18673$ industrial loans), CAL. FIN. CODE $\$ 22467$ (personal property brokers), CAL. FIN. CODE $\$ 22468$ (small loans); CoNN. GEN. STAT. Rev. 36-236 (1958) (small loan contracts), 2-88 1958) (retail sales contract); MD. ANN. CoDE art. 58A, §19 (1957) (small loans), art. 11, - 198 (1957) (industrial finance contracts), art. 83, §130 (1957) (retail installment contracts, $\$ 2,000$ or less where the seller has retained a security interest); MINN. STAT. $\$ 56.12$ ( 957) (small loans), §168.71A(2) (1947) (motor vehicle retail sale); N.Y. BANKING Laws § 353 (small loans), N.Y. Pers. Prop. LAWs \$ 302(13) (retail installment contracts); Ore. 
In the four states having no general statutes, 121 three prohibit their use by small loan companies, 122 and one says no in automobile retail sales. ${ }^{123}$

Out of this welter of partial and complete regulation there emerges a general pattern of restriction. This pattern shows, over the past fifty years, a slow but persistent increase in the number and types of restrictions. Although there is some indication that in the last ten years the state legislatures have tightened up these restrictions, 124 there has been no dramatic rewriting of the prohibition statues. However, only Illinois, Pennsylvania, and Ohio specifically allow for and do not, in some way, restrict cognovits. They stand in splendid isolation, and, understandably, it is these states that produce the overwhelming bulk of cognovit judgments. 125

The total impact of this legislative policy suggests, however, that there is a growing, and with a few notable exceptions, a near unanimous feeling of distaste for this time-honored method of obtaining jurisdiction.

State supreme court cases also evidence a distaste toward cognovits. The existing case law can be divided into two categories. First there are those cases construing the local substantive and procedural rules on cognovits. Here distaste is well illustrated by the extreme liberality of trial courts in opening up a cognovit judgment on a showing, however weak, by the defendant that he has a substantive defense. 126 Consistently, in the rare attempts to use cognovits in states that place restrictions on them, 127 the court can be tough. For instance, in Barnes v. Hilton, 128 the California Court of Appeals displayed its displeas-

REv. STAT. \$ 83.670(1) (1950) (motor vehicle retail sales), \$725.050 (1955) (small loans).

Idaho, Iowa, Nebraska, and South Dakota adopted general retail or motor vehicle retail sales acts, but did not add to their general procedural limitations on cognovits. North Carolina, Oklahoma and Wyoming likewise ignored anti-cognovit clauses in their small loan laws. Kansas ignored cognovits in both types of acts.

121 See note 91 supra.

122 Me. Rev. Stat. ANN. ch. 59, § 220 (1954); N.H. Rev. Stat. ANN. $\$ 399.28$ (1955); R. I. GEN. LAWS ANN. \& 19-25-24 (1956).

123 Colo. Rev. Stat. ANN. \$ 13-16-6(1)(b) (1953). Maine and New Hampshire have motor or general retail sales acts but no restrictive clause. Colorado has a small loan law without restriction.

124 This increase mainly occurs in the new sales finance acts in which many states have included anti-cognovit sections.

125 See note 26 supra and accompanying text.

126 See, e.g., Thrifti-Pak Home Appliance, Inc. v. Kowalcayk, 22 Ill. App. 2d 536, 161 N.E.2d 344 (1959); L. \& N. Sales Co. v. Stuski, 188 Pa. Super. 117, 146 A.2d 154 (1958), where appellate courts reversed trial courts refusal to open. See also Note, 102 U. PA. L. REv. 524, 531-32 (1954); Hunter, The Warrant of Attorney to Confess Judgment, 8 OHIo ST. L. J. 1, 12-16 (1941), for a discussion of the local practice. Several attorneys for finance companies pointed out that it is a common practice for trial judges to freely allow the defendant's motion. See note 65 supra and accompanying text.

127 See note 92 supra and accompanying text.

128118 Cal. App. 2d 108, 257 P.2d 98 (1953). 
ure by allowing a defendant to vacate a trial court judgment based upon a cognovit. The California Code ${ }^{129}$ requires the defendant to verify by oath the fact that he owed the money before a plaintiff may take judgment by confession. The plaintiff tried to use an ordinary cognovit clause and had the attorney acting under that clause file the proper oath. The clause itself was unverified. The court said "[I]f [plaintiff's] arguments were upheld, then the provisions of the code here involved could readily be converted by the simple device of including in any promissory note a warrant of attorney, whereby any attorney could make a statement in writing, verify it, and could pass judgment. Clearly, such is not the policy contemplated by the legislature."130 There are other examples of local dissatisfaction, 131 but none of successful constitutional attacks. ${ }^{132}$

The other large area of litigation occurs when the lender attempts to enforce its $F 1$ cognovit judgment in $F 2$. Here the $F 2$ court is faced with a constitutional demand that it give full faith and credit to the judgment of a sister state. Since most states limit the use of cognovits, in one fashion or another, F2 normally has a local policy inimical to the foreign judgment.

129 CAL. CIv. Proc. CODE $\$ 1133$.

130118 CaI. App. 2d at 111, 257 P.2d at 99. This approach should be contrasted to that of the Kansas Supreme Court. In Barnes v. Hilton, 172 Kan. 345, 239 P.2d 236 (1952), the Kansas Supreme Court, sitting as an F2 court in a suit on the original trial court judgment in the above case, held that the plaintiff was entitled to judgment despite the defendant's argument that the cognovit clause did not authorize the attorney to file the verified oath required by the California statute. The court suggested two reasons. First that the cognovit authorized the attorney's oath, and secondly, citing an earlier non-cognovit clause case, Smith v. State, $64 \mathrm{Kan} .730,68$ Pac. 641 (1902), that in Kansas, as between the parties, the affidavit is not required. The second reason may make sense in terms of the fact that the procedural statutes were to cover confessions after suit was filed in any type of case, not just to cover cognovits as a basis of jurisdiction. If the reason for the statute is to protect creditors against a debtor confessing judgment to a "friend" in order to escape paying his real creditors, there is no need to protect the defendant by having him file an affidavit. See Note, 21 NotRe DAME LAw. 187, 188 (1946), where the writer discusses some early Indiana cases taking the Kansas view at a time when Indiana had a California-Kansas type statute.

In those states with California-Kansas type limitation statutes, a lender may be able to induce the court to follow the Kansas example and either to waive the requirement of an affidavit as between the parties or to allow the cognovit clause to contain an authorization that the attorney file the affidavit. If successful, this argument might increase the number of states in which a cognovit could be used.

131 See, e.g., General Contract Purchase Corp. v. Max Keil Real Estate Co., 35 Del. 531, 170 Atl. 797 (Super. Ct. 1933); First Nat'l Bank v. White, 220 Mo. 117, 120 S.W. 36 (1909). Even in the states where cognovits are popular, the court may get testy. In Frantz Tractor Co. v. Wyoming Valley Nursery, $384 \mathrm{~Pa}$. 213, 120 A.2d 303 (1956), the court vacated a concession judgment when the cognovit clause appeared on the reverse side of an equipment lease on the grounds that the defendant had signed only on the front. The court's language is particularly vehement.

132 Most of the local cases are beyond the scope of this study since they decide questions of local procedure only. For a detailed review of these cases in various states, see Hunter, The Warrant of Attorney to Confess Judgment, 8 OHIO ST. L.J. 1 (1941) (Ohio); Note, 102 U. PA. L. Rev. 524 (1954) (Pennsylvania); Note, 21 Notre DaME Law. 187 (1946) (Indiana). For a more limited review, see Note, 46 ILL. L. REV. 642 (1951) (Illinois). 
A review of the traditional wisdom 133 illustrates a wide variety of attempts by the defendant, sometimes successful, to induce F2 to give effect to its local policy.134 Defendants' claims divide into five areas: (1) The local policy of F2 is a sufficient reason for denying full faith and credit; (2) A cognovit judgment violates due process in that the defendant has no notice or opportunity to defend; (3) In "fact" the cognovit did not grant jurisdiction to F1; (4) There is a valid defense under the law of F1; and (5) In "law" the consent did not give jurisdiction to $\mathrm{Fl}$ since the consent was prohibited by its "proper" law. 135

The first two claims do not convince $F 2$ courts. They proclaim that a local policy inimical to cognovits is an insufficient ground for denying full faith and credit. 136 The extremely common argument that lack of notice and opportunity to defend deprived the defendant of due process of law, is also singularly unsuccessful. Normally there is no discussion. ${ }^{137}$

133 The proper (constitutional) approaches that an F2 court may use will be discussed in the third section of this article.

134 Or on occasion the policy of some third state.

135 On occasion an F2 court will base its decision on some other ground. One semi-popular method of preventing a plaintiff from enforcing his judgment is to find that the plaintiff has procedurely failed to show the validity of the F1 judgment. The plaintiff may fail to show that F1 authorizes cognovits. Since F2 prohibits or limits them, the court rules that it will assume that, without a showing by plaintiff, the law of $F 1$ must be the same as that of $F 2$. See, e.g., United Mercantile Agencies v. Bissonnette, 155 Fla. 22, 19 So. 2d 466 (1944); McNair v. Underwood, 55 Okla. 585, 155 Pac. 553 (1916). Sometimes plaintiff loses merely because he does not correctly present a transcript of the F1 judgment. See, e.g., Picking v. Local Loan Co., 185 Md. 253, 44 A.2d 462 (1945). Compare Bonnet-Brown Sales Serv. v. Utt, 323 Mo. 589, 19 S.W.2d 888 (1929), where the transcript was apparently correct, but the wording of the Illinois judgment was faulty. See Annot., 162 A.L.R. 685 (1946). Other defendants have successfully argued the escape device of fraud in the procurement. See, e.g., Consumer Credit Co. v. Bowers, 143 W. Va. 748, 104 S.E.2d 869 (1958)(signature of defendant to cognovit obtained through fraud), or the non-finality of the judgment. See, e.g, Suydam v. Bank of Silver Spring, 233 F.2d 21 (D.C. Cir. 1956). In Bland v. White, 138 Misc. 715, 246 N.Y.S. 532 (1930), and Baldwin Bldg. \& Loan Ass'n v. Klein, 136 Misc. 752 240 N.Y.S. 804 (Sup. Ct.), aff'd mem., 230 App. Div. 830, 244 N.Y.S. 899 (1st Dep't. 1930), 44 HARV. L. REv. 1275 (1931), the New York courts refused to give full faith and credit because defendants were residents of New York.

136 See, e.g., W. H. Barber Co. v. Hughes, 223 Ind. 570, 63 N.E.2d 417 (1945); Wedding v. First Nat'l Bank, Inc., 280 Ky. 610, 133 S.W.2d 931 (1939); McDade v. Moynihan, 330 Mass. 437, 115 N.E.2d 372 (1953), 39 A.L.R.2d 1232 (1955). Almost all of the cases cited in the subsequent notes specifically so hold. In Monarch Refrigerating Co. v. Faulk, 228 Ala. 554, 155 So. 74 (1934), the Alabama court denied full faith and credit on other grounds, but also suggested that since cognovits were locally against public policy, it could deny a court the enforcement of the F1 judgment, citing Wisconsin v. Pelican Ins. Co., 127 U.S. 265 (1888), and Anglo-American Prov. Co. v. Davis Prov. Co., 191 U.S. 373 (1903). However, in Ohio Bureau of Credits v. Steinberg, 29 Ala. App. 515, 199 So. 246 (1940), the court recognizes that this approach is no longer valid, citing Titus v. Wallick, 306 U.S. 282 (1939).

137 See, e.g., Turner v. Alton Banking \& Trust Co., 181 F.2d 899 (8th Cir.), cert. denied, 340 U.S. 833, rehearing denied, 340 U.S. 885 (1950); Bond v. Farmers \& Merchants Nat'l 
Defendants frequently realize that local policy and lack of notice are not going to be sufficient. So they claim that lack of jurisdiction in F1 is a sufficient ground for F2 to refuse full faith and credit. This claim is supported in various ways. F2 courts allow defendants to successfully show that in "fact" no consent was given by showing that the defendant did not sign the note, 138 that the cognovit clause was forged, 139 that the contract, containing the cognovit, was rescinded for fraud, 140 or that the defendant was not authorized to sign the cognovit.141 Sometimes, relying on two United States Supreme Court cases, 142 the F2 court finds by giving a "strict" construction to the grant of power in the cognovit that in "fact" consent was not given. ${ }^{143}$

Rarely, a defendant will argue, sometimes successfully, that under the substantive or procedural law of $F 1$ the cognovit did not give the F1 court jurisdiction or rendered the judgment void and subject to collateral attack.144

Bank, 64 Cal. App. 2d 842, 149 P.2d 722 (1944); Cocke v. Truslow, 91 Ga. App. 645, 86 S.E.2d 686 (1955); Dickson v. Lindsey, 234 Miss. 684, 107 So. 2 d 732 (1958); Hazel v. Jacobs, 78 N.J.L. 459 , 75 Atl. 903 (1910).

In Ellwanger v. Agostos, 255 S.W.2d 492 (Ky. 1953), the defendant argued that the Illinois judgment contravened the Kentucky constitution in that it deprived her of her day in court. The Kentucky Supreme Court had no trouble in denying this plea. For additional discussion and cases, see Annot., 39 A.L.R.2d 1232, 1235 (1955).

138 First Nat'l Bank v. Brown, 119 Fla. 761, 162 So. 142 (1935).

139 Anderson v. Reconstruction Fin. Corp., 281 Ky. 531, 136 S.W.2d 741 (1940).

140 Brone v. Golde, 267 N.Y. 284, 196 N.E. 58 (1935).

141 In Monarch Refrigerating Co. v. Farmers' Peanut Co., 74 F.2d 790 (4th Cir. 1935), the court rejected the defendant's argument that the officers of a corporation had no power to sign a cognovit on the grounds that the local anti-cognovit statute was only procedural. However, the case was remanded so that the defendant could show, by answer, that in fact the officers were not authorized.

142 National Exch. Bank v. Wiley, 195 U.S. 257 (1904); Grover \& Baker Mach. Co. v. Radcliff, 137 U.S. 287 (1890). Not all the cases cite these two cases, but they should, as they are the constitutional authority.

143 See, e.g., Bower v. Casanave, 44 F. Supp. 501 (S.D.N.Y. 1941) (defense that the plaintiff not the owner or holder sustained); Gundlach v. Park, 140 Minn. 78, 165 N.W. 969 , aff'd on rehearing, 140 Minn. 78, 167 N.W. 302 (1918) (judgment broader than cognovit); Bonnet-Brown Sales Serv. v. Utt, 323 Mo. 589, 19 S.W.2d 888 (Ct. App. 1929) (cognovit granted power to attorney; no showing that attorney appeared); Antonelli v. Silvestri, 137 N.E.2d 146 (Ohio App. 1955) (name of plaintiff not clear in cognovit, judgment taken by an "esquire").

${ }^{144}$ See, e.g., First Nat'l Bank v. Cunningham, 48 Fed. 510 (D. Ky. 1891) (citing F1 law that payment prior to judgment renders the judgment void since the consent disappears); Markham v. Nisbet, 60 So. 2d 393 (Fla. 1952) (citing F1 law that if the F1 statute of limitations has run the cognovit is void); Gordon v. Heller, 271 Mich. 240, 260 N.W. 156, cert. denied, 296 U.S. 619 (1935) (same); Wilensky v. Miller, 257 Wis. 589,44 N.W.2d 521 (1950) (citing F1 law that the dissolution of a joint corporate maker voids the cognovit).

In several cases the defendant cited F1 lav: but the court granted full faith and credit on the grounds that the defendant had not shown, under the law of $F 1$, that the $F 1$ judgment w.as in any way invalid. See, e.g., Turner v. Alton Banking \& Trust Co., 181 F.2d 899 (8th Cir.), cert. denied, 340 U.S. 833, rehearing denied, 340 U.S. 885 (1950) (statute of limitations, 
The most interesting area of attack turns on inducing the F2 court to combine concepts of choice of law and lack of jurisdiction. If all of the elements of the transaction-place of making, place of performance, place intended by the parties, place with the most significant contacts-occur in the state rendering judgment, F2 will almost automatically give full faith and credit to the F1 judgment. ${ }^{145}$ But, if one or more of these elements occur in the F2 state or in some third state, the defendant argues that the "proper" law governing the contract, and hence the validity of the consent, is some law prohibiting or limiting cognovits. Whether the defendant is successful depends, for almost all F2 courts, on which contract choice of law rule the F2 court adopts. Frequently the F2 court will adopt as the "proper" law, the place of the making of the note. If that "place" 146 is in a state allowing cognovits, $147 \mathrm{~F} 2$ will give full faith and credit. 148 If it is a state prohibiting or limiting cognovits, ${ }^{149} \mathrm{~F} 2$ will refuse to give full faith and credit.150 In "place of making" cases the courts

judgment not in county where executed, cognovit exhausted after original judgment); Monarch Refrigerating Co. v. Farmers' Peanut Co., 74 F.2d 790 (4th Cir. 1935) (judgment on an unliquidated amount); Dickson v. Lindsey, 234 Miss. 684, 107 So. 2d 732 (1958) (judgment before maturity of note). In Smith v. Swart, 103 N.J.L. 150, 134 Atl. 755 (1926), the court denied defendant the right to attempt to show that the $F 1$ judgment was on an unliquidated amount. On occasion the defendant does not cite the F1 law which might void the judgment and the F2 court treats the issue as being on the merits and so foreclosed. See, e.g., Hazel v. Jacobs, 78 N.J.L. 459, 75 Atl. 903 (1910) (defendant claimed payment prior to the F1 judgment).

145 See, e.g., Cocke v. Truslow, 91 Ga. App. 645, 86 S.E.2d 686 (1955) (court found it immaterial that defendant was a Georgia resident); McDade v. Moynihan, 330 Mass. 437, 115 N.E.2d 372 (1953); Dickson v. Lindsey, 234 Miss. 253, 107 So. $2 d 732$ (1958).

146 The courts frequently manipulate what constitutes "making" in order to arrive at the result it wants. Typical examples include Loundonville Milling Co. v. Davis, $248 \mathrm{Ala} .202$, 27 So. 2d 6 (1946), where the court equated "making" with the signing of the note. The note was signed in Alabama and was to be accepted in Ohio. In Note, 8 AtA. LAw. 178 (1947), the student writer is horrified at this manipulation to help an Alabama citizen. In Ohio ex rel. Squire v. Eubank, 295 Mich. 230, 294 N.W. 166 (1940), the court found a renewal note "made" in Ohio, although signed in Michigan.

147 Normally F1.

148 Tumer v. Alton Banking \& Trust Co., 181 F.2d 899 (8th Cir.) cert. denied, 340 U.S. 833, rehearing denied, 340 U.S. 885 (1950); Ohio Bureau of Credits v. Steinberg, 29 Ala. App. 515, 199 So. 246 (1940); Carroll v. Gore, 106 Fla. 582, 143 So. 633 (1932).

149 Normally F2.

150 See, e.g., Monarch Refrigerating Co. v. Faulk, 228 Ala. 554, 155 So. 74 (1934) (also relied on the old right to deny a court to a foreign cause of action); Pearson v. Friedman, 112 So. 2d 894 (Fla. Dist. Ct. App. 1959) (but some indication that the F1 choice of law rule was important. Id. at 895 n.2); Acme Feeds, Inc. v. Berg, 231 Jowa 1271, 4 N.W.2d 430 (1942); Jones v. Turner, 249 Mich. 403, 228 N.W. 796 (1930); Bernard Gloeckler Co. v. Baker Co., 52 S.W.2d 912 (Tex. Civ. Ct. App. 1932) (also relied on assumed intention of the parties).

Even F1 courts will renounce jurisdiction on occasion when the defendant convinces it that by the law controlling the cognovit, determined by Fl's choice of law rule, the cognovit did not grant Fi jurisdiction. See, e.g., Gramatan Nat'l Bank v. Barron, 193 Md. 649, 69 
talk in terms of the non-existance of a valid consent.151

Other contact points used to find the proper law include: place of payment; ${ }^{152}$ place of expressed153 or assumed intention of the parties; 154 or the so-called "center of gravity" (place of most significant contacts). 155 No matter what contact point or combination of contact points the F2 courts find determinative of the "proper" law governing the contract, they all assume, without discussion, that it is the F2 choice of law rule that determines the "proper law." No case was found in which F2 felt compelled to use F1's choice of law rules. 156

A.2d 489 (1949), 19 A.L.R.2d 540 (1951); Albert v. Sitton, 170 N.E.2d 925 (Ohio Ct. Com. Pl. 1959). But see Davis v. Wirth, 249 Ill. App. 544 (1928) and Davis v. Mosbacher, 252 III. App. 536 (1928) where the F1 court apparently found the proper law to be that of the place "where it is delivered." Ia. at 543. The fact that the "place of making" statute only places procedural limitations or by its terms prohibits the entering of judgment by the "place of making" courts rather than rendering the cognovit clause void does not bother F2 courts protecting the local citizen. See, e.g., Loundonville Milling Co. v. David, 248 Ala. 202, 27 So. 2d 6 (1946); Acme Food Co. v. Kirsch, 166 Mich. 433, 131 N.W. 1123 (1911). But see Gotham Credit Corp. v. Powell, 22 N. J. Misc. 301, 38 A.2d 700 (1944), where the court found that although the note was executed in New Jersey, the local statute was procedural and should not have extraterritorial force. In Gramatan Nat'l Bank v. Barron, supra, the Maryland court, an F1 court, refused jurisdiction when the note, executed in Virginia, did not specify a particular attorney. The Virginia statute so required prior to entry of judgment in Virginia.

151 See, e.g., Monarch Refrigerating Co. v. Faulk, supra note 150; Acme Food Co. v. Kirsch, supra note 150; Bernard Gloeckler Co. v. Baker Co., supra note 150. Although not mentioned by any of the cognovit cases, the argument would seemingly involve the famous logical problem known as the Bootstrap Doctrine. "But an agreement is not a contract, except as the law says it shall be, and to try to make it one is to pull on one's bootstraps." Per Judge Hand in E. Gerli \& Co. v. Cunard S. S. Co., 48 F.2d 115, 117 (2d Cir. 1931). Today the Bootstrap is no longer bothersome. Restatement (SECOND), Confict of Laws $\S 332$ a (Tent. Draft No. 6, 1960).

152 See, e.g., South Orange Trust Co. v. Barrett, 76 A.2d 310 (Del. Super. Ct. 1950) (Maryland judgment, payable in New Jersey; full faith and credit denied in Delaware since New Jersey requires cognovit to be under seal); Egley v. T. B. Bennett \& Co., 196 Ind. 50, 145 N.E. 830 (1924) (found to be F1, judgment enforceable); Greenbaum Sons' Bank \& Trust Co. v. Porth, 116 Kan. 310, 226 Pac. 747 (1924) (same); Wedding v. First Nat'l Bank, 280 Ky. 610, 133 S.W.2d 931 (1939) (presumed intention of the parties) (same).

153 Mountain States Fixture Co. v. Daskalos, 61 N.M. 491,303 P.2d 698 (1956) (found to be $F 1$, judgment enforceable despite invalidity at place of making, F2).

154 Bernard Gloeckler Co. v. Baker Co., 52 S.W.2d 912 (Tex. Civ. Ct. App. 1932) (found to be F2, judgment not enforceable).

155 W. H. Barber Co. v. Hughes, 223 Ind. 570, 63 N.E.2d 417 (1945). The court found the contract to be governed by Illinois law even though signed in Indiana. In Spahr v. P. \& H. Supply Co., 223 Ind. 59163 N.E.2d 425 (1945), the court found the contract to be governed by Ohio law even though payable in Indiana. In both cases the "most" contacts occurred in $\mathrm{Fl}$.

156 See note 249 infra and accompanying text for a suggestion as to the unanimous error of the F1 courts. 


\section{Due Process and Futr Farth and Credit}

A critical review of the attitudes and practices of the finance industry and of the traditional legislative and judicial wisdom suggests the desirability of a revaluation of the status of cognovits. While state legislatures could act, the possibility of such a revaluation is likely to arise out of the new concepts in due process and full faith and credit.

\section{Due Process}

First, the due process argument may arise when some defendant appeals to the United States Supreme Court from an F1 court denial of his plea that cognovits violate the fourteenth amendment. The defendant has two theories to urge. He could suggest that by 1961 , "consent," when embodied in a cognovit clause, is not a reasonable contact, 157 and so is not a basis for in personam jurisdiction. He could also argue that even if "consent" were sufficient, any statute or procedure that does not require notice violates due process.

The arguments against a defendant succeeding on his first theory are impressive. Neither text writers ${ }^{158}$ nor the second edition of the Restatement, 159 see any problem in consent jurisdiction, cognovit or otherwise. Even Professor Ehrenzweig finds only an extremely remote procedural due process argument. 160 And Professor Paulsen maintains: "Perhaps, judgments grounded in these consents [cognovits] are not in accordance with 'fundamental principles of justice and fair play.' There is little to suggest that the court [United States Supreme Court] would take that tack, involving, as it would, the outlawing of cognovit notes in those states which have seen no need to forbid them."161 Lower federal and state judicial opinions give little hope.162 The United

157 See, e.g., International Shoe Co. v. Washington, 326 U.S. 310 (1945).

is8 GOODRICH \& 73, at 196; LEFLAR § 29; STUMBERG 81.

159 RESTATEMENT (SECOND), CONFLICT OF LAWS $\$ 81$ (Tent. Draft No. 3, 1956). See note 8 supra.

160 Professor Ehrenzweig states that consent is a valid basis of jurisdiction. EkRENZwEIG \$27, at 89. In \& 55 concerning recognition of $F 1$ judgments, he discusses cognovits under "Unfair Procedure" and impliedly finds that they are not unfair. See note 242 infra and accompanying text for a fuller discussion.

161 Paulsen, Enforcing the Money Judgment of a Sister State, 42 Iowa L. REv. 202, 210 (1957).

102 No F2 court has given dignity to a defendant's plea that jurisdiction based on a cognovit is invalid, even when he argued lack of notice and opportunity to defend. See note 137 supra. The question has been raised but seldom in an Fl court. Although not a true "cognovit" case, in Green Mountain College v. Levine, 120 Vt. 332, 139 A.2d 822 (1958), the college obtained a signature of the defendant to a note which appointed the Vermont Secretary of State to receive process. Despite the fact that there were no statutory provisions for the Secretary receiving it, the court found that the defendant had consented to jurisdiction and had waived any lack of power in the Secretary of State to forward notice. The court quoted from Gilbert v. Burnstine, 255 N.Y. 348, 174 N.E. 706 (1931), an ordinary consent case, to 
States Supreme Court, although showing distaste, impliedly has recognized their validity. 163

Despite this monolithic approval, a few arguments are available to the United States Supreme Court. If the test is that of "reasonableness," the Court should distinguish between ordinary "consent" cases and those involving "cognovits." While the argument favoring consent in Gilbert v. Burnstine that "Our government is not so paternalistic as to prevent them,"164 may well apply to an ordinary "consent" agreement, 165 it should not apply to an adhesion cognovit note. Not only do courts protect the defendant from his "choice" in an adhesion contract in the conflict of laws, 166 but this man-child

the effect that individuals should be allowed to contract as they please so long as there is no violation of a constitution or public morality. Apparently Vermont found none. That Vermont prohibited a cognovit clause was not mentioned. See VT. STAT. ANN. tit. $12 \S 4671$ (1959).

Eariy cases like Hutchinson v. Palmer, 147 Ala. 517, 40 So. 339 (1906) and Houpt v. Bohl, 71 Ark. 330, 75 S.W. 470 (1903), assume constitutionality without discussion.

Cases like Hamilton v. Schoenberger, 47 lowa 385 (1877) and First Nat'l Bank v. White, $220 \mathrm{Mo} .717,120$ S.W. 36 (1909), do not help the defendant. They do not allow a Jocal cognovit judgment, but do so on the basis of the lack of local statute or of a local public policy. There is no suggestion that given a statute allowing such judgments, the courts would find the policy strong enough to hold the statute unconstitutional.

163 National Exchange Bank v. Wiley, 195 U.S. 257 (1904); Grover \& Baker Sewing Mach. Co. v. Radcliffe, 137 U.S. 287 (1890).

164255 N.Y. 348, 355, 174 N.E. 706, 707 (1931).

165 In Gilbert importers of zinc agreed to consent to arbitration in Great Britain.

166 Ehrenzweig, Adhesion Contracts in the Confict of Laws, 53 CoLum. L. REv. 1072 (1953). He defines "adhesion" as "agreements in which one party's participation consists in his mere "adherence' unwilling and often unknowing, to a document drafted unilaterally and insisted upon by what is usually a powerful enterprise." Id. at 1075. Certainly to the bulk of defendants, a cognovit note qualifies. Even a large corporate defendant may qualify. Pressure is applied to the large defendant to sign a note containing the clause. See note 81 supra and accompanying text. While there may be theoretical bargaining power between the parties, in fact there probably is not, since the defendant would not be willing to lose the loan in order to hold out for the removal of the cognovit clause. Professor Ehrenzweig takes a narrower view, supra at 1076, but size does not necessarily determine adhesion. Not all terms of a contract have equal bargaining weight. In the adhesion article, Professor Ehrenzweig cites usury and insurance cases, but does not mention cognovits. However, in his major article on contracts, Ehrenzweig, Contracts in the Confict of Laws-Part One: Validity, 59 Colum. L. REv. 973 (1959), he cites, id. at 1020, cognovits as an exception to his Rule of Validation on the grounds that the law of the lex fori is used, when there is a strong local policy, "to problems connected with the enforcement process." Id. at 1019. In Frantz Tractor Co. v. Wyoming Valley Nursery, 384 Pa. 213, 120 A.2d 303 (1956), the Pennsylvania court, although not using the word "adhesion," vacated a cognovit judgment because the cognovit clause appeared on the reverse side of an equipment lease and the defendant had signed only on the front. The opinion is almost a classic example of a court manipulating normal contract rules to nullify an adhesion contract. The language is particularly strong. In Note, 44 HARv. L. REv. 1275 (1931), the writer makes an early attempt to equate cognovits with the concept of an adhesion contract. He suggests that an F2 court might refuse to recognize an F1 cognovit judgment because the consent was obtained through "economic duress." 
is protected in many other areas in this highly complex world. 167 Although most writers have considered "adhesion" only in terms of manipulating substantive doctrines, in the name of public policy, to protect the little man, still when the consequences are "unreasonable" in the jurisdictional sense, the elevation of public policy to the due process level seems in order.

The editors of the Harvard Law Review, in their discussion of state court jurisdiction, ${ }^{168}$ even suggest that, as to all consents prior to suit, the constitutionality of the jurisdiction may depend on "the relative bargaining positions of the parties and their reasons for having chosen the particular forum." 169 They add: "[J]urisdiction should be disclaimed ... in extreme cases, as a matter of due process, when the note is coercive or involves the selection of a grossly inconvenient forum."' 170

The argument against cognovit consent as a basis of jurisdiction might be limited to the situation where the little defendant is a non-resident, on the grounds that consent to jurisdiction in a local court is not a "grossly inconvenient forum." Yet a resident of Springfield, Illinois, must travel further to Chicago than must a resident of Gary, Indiana. If due process, in the future, restricts the sheriff in serving the transient, 171 the stay-at-home defendant, even though "consenting," and a resident, should not have to travel the length of the state. Certainly an "adhesion" cognovit is as "coercive" to a resident as a nonresident.

As reported above, the industry attorneys are split, but many indicate that cognovits are disliked, are used only because of the competition, and could be outlawed without basically disrupting the finance industry. Granted that several attorneys correctly argue that cognovits must be examined in terms of other creditor remedies-garnishment and future assignment of wages-the fact that other remedies may be distasteful does not force a conclusion that the industry must be allowed the cognovit remedy. The argument that strong remedies are needed to induce the finance industry to support the credit economy is greatly overworked. People borrow money in non-cognovit states. Illinois practice is sordid. The fact that three states still allow their use seems somewhat unnatural. This is not a new area of experimentation, but a dying area hanging over from the nineteenth century and caveat emptor. Given almost universal condemnation by state legislation, hostility by many leaders in the industry, increasing protection by the courts, and a general feeling of dis-

167 Oldfather, Complexity, Concentration and Children-The Significance of Insurance Law, 9 KAN. L. REv. 1 (1960); Kessler, Contracts of Adhesion-Some Thoughts About Freedom of Contract, 43 ColuM. L. REv. 629 (1943).

168 Developments in the Law-State Court Jurisdiction, 73 HARv. L. REv. 909 (1960).

$169 \mathrm{Id}$. at 944.

$170 I d$. at 945 .

171 See EHRENZWEIG § 30. 
taste for such procedure, the United States Supreme Court might be willing to break the whole field wide open. 172

The broadside attack on the adhesion consent-the cognovit-may fail to induce the Court to prohibit consent as a jurisdictional base. But in addition to marshalling all of the general policy arguments against cognovits, the defendant should also shout that when the cognovit does not, and it almost always does not, provide for any notice to the defendant, it surely denies due process.

Notice, in in personam actions, has infrequently been a problem.173 Since service of process and summons within the state was the traditional method of obtaining jurisdiction, notice was part of the procedure of acquiring jurisdiction. Early expansion of the jurisdictional base relied on the express or implied consent of the defendant to the appointment of a statutory agent for the service of process. ${ }^{174}$ Again no problem of notice existed, since the agent received notice and sent it on to the defendant. Later, with domicle175 or "minimum contacts" 176 as a jurisdictional base, the Court found mailed notice to the defendant sufficient to meet the requirement of due process. Today the fiction of service of process within the state is no longer needed. Notice is sent directly to the out-of-state defendant. 177

Early in the development of new jurisdictional bases, the United States Supreme Court struck down, in Wuchter v. Pizzutti, 178 a non-resident motorist statute. It made no provision for the Secretary of State to give mail notice to the defendant. The Court said: "[A] provision of law for service that leaves open such a clear opportunity for the commission of fraud ... or injustice is not a reasonable provision, and ... would certainly be depriving a defendant of his property without due process of law."179 The Court brushed aside the argument from Hess v. Pawloski180 and other cases that the defendant had "consented" to such service. This was "enforced acceptance."181

172 Ferguson v. Georgia, 365 U.S. 570 (1961), indicates that the United States Supreme Court is willing to apply the fourteenth amendment to restrict a common law procedure in a criminal action. Mere antiquity is no guarantee of due process. But see RESTATEMENT (SECOND), CoNfLICT of Laws \$ 74, comment b, at 45 (Tent. Draft No. 3, 1956): "Nor is a common law, rule [of jurisdiction] likely to be departed from on the ground that it is inreasonable."

173 See McDonald v. Mabee, 243 U.S. 90 (1917) for the old lead case.

174 See, e.g., Lafayette Ins. Co. v. French, 59 U.S. (18 Hö.) 404 (1856).

175 Milliken v. Meyer, 311 U.S. 457 (1940).

176 International Shoe Co. v. Washington, 326 U.S. 310 (1945).

177 See, e.g., Travelers Health Ass'n v. Virginia ex rel. State Corp. Comm'n, 339 U.S. 643 (1950); ILI. REV. STAT. ch. 110, \$17 (1959).

178276 U.S. 13 (1928).

179 Id. at 19.

180274 U.S. 352 (1927).

181276 U.S. at 19. In Washington ex rel. Bond \& Goodwin \& Tucker, Inc. v. Superior Court, 289 U.S. 361 (1933), the Court upheld a statute not requiring notice. However the 
Starting in 1950, the United States Supreme Court in a series of notice cases re-examined the whole problem. In Mullane v. Central Bank \& Trust Co., 182 the Court refused to classify the case as in personam or in rem, but required, in a trust accounting case, "notice reasonably calculated, under all the circumstances, to apprise interested parties of the pendency of the action ....."183

The Court suggested that the defendant-trustee had a duty to search the record to find names and addresses and once this was done, he should mail notice to those addresses. In later cases, 184 the Court reaffirmed and expanded the new due process test. Although primarily in rem cases, the logic suggests that in any action the best notice possible must be given. The plaintiff may only plead undue burden in finding the defendant's address. 185

The issue for cognovits, in light of these cases, resolves itself into a relatively simple question: May a defendant "voluntarily" waive this due process notice requirement prior to suit? As stated at the first of this article, the text writers 186 and the new Restatement of Conflicts 187 not only agree that consent is valid, but that consent may waive any notice. But even if there were freedom of contract in fact, freedom to waive such a jealously guarded right as notice might well be doubted. If cognovits are adhesive, the defendant's "consent" is no more than an "enforced acceptance," stiuck down in Wuchter v. Pizzutti.188 A few dissenting judges ${ }^{189}$ and the editors of the Harvard Law Re-

Court used the now discredited distinction on the power of a state to exclude a foreign corportation. The Court also pointed out that the corporation could have appointed someone to receive process after it left the state.

182339 U.S. 306 (1950).

183 Id. at 314.

184 Wisconsin Elec. Power Co. v. Milwaukee, 352 U.S. 948 (1956) (per curiam) (tax assessment); Walker v. City of Hutchinson, 352 U.S. 112 (1956) (eminent domain); Covey v. Town of Somers, 351 U.S. 141 (1956) (tax foreclosure); City of New York v. New York, N.H. \& H.R.R., 344 U.S. 293 (1953) (bankruptcy reorganization). In Walker v. City of Hutchinson, supra, the Court required at least mail notice to a known resident in an eminent domain proceedings.

185 The notice cases have occasioned a flurry of notes. See, e.g., Note, 70 Harv. L. Rev. 1257 (1957); Note, 32 IND. L. REV. 469 (1957).

186 See note 12 supra.

187 See note 13 supra.

188 See Mr. Justice Brandeis' dissent, Mr. Justice Holmes concurring, in Wuchter y. Pizzutti, 276 U.S. 13, 25-28 (1928).

189 Justice Hulburd, with Justice Adams, of the Vermont Supreme Court, dissented in Green Mountain College v. Levine, 120 Vt. 332, 139 A.2d 822 (1958), discussed in note 162 supra. He said: "Whether one expressly consents to jurisdiction or whether that consent may be said to exist on the basis of a fiction as in the non-resident motorist cases, still notice to the defendant is essential and where there is no such adequate provision for notice to the defendant as to make it reasonably probable that such notice will be communicated to the defendant, service is invalid as lacking due process of law." Id. at 339,139 A.2d at 826. In Midessa Television Co. v. Motion Pictures for Television, 290 F.2d 203 (5th Cir. 1961), an ordinary consent case, the court gave full faith and credit to a New York judgment. While 
view190 are disturbed. The cognovit should be re-examined in the light of the new cases.

The essence of the new notice cases ${ }^{191}$ is the belief that the defendant should have notice. Only the necessities of business and the need for settling disputes in one law suit allow a lesser standard. The finance industry has not shown that even cognovits are needed. Certainly they have not shown that a consent to jurisdiction and confession of judgment without notice is needed. The industry could retain all of the legitimate advantages of cognovits-obtaining jurisdiction over skipping or non-resident defendants; quick judgment on all valid claims and the accompanying lien-and still give the defendant notice, either personally or by mail to the last known address. Arguments of crowded court calendars and insubstantial defenses are weak. If most claims are just, defendants will not hire an attorney and defend. But at least the defendant would have had notice!192 Requiring notice would have no effect in the area of consent, actual or implied, after the suit is commenced. In those cases the defendant is apprised of the suit and notice is not needed. Therefore, a holding of unconstitutionality by the United States Supreme Court would not disrupt the traditional "waiver of summons and entry of appearance." Nor need such a holding in any way disrupt the right of a state to require a non-resident defendant, be it a corporation or individual, to appoint a local agent for the service of process. In such cases the defendant, through his appointed agent, will receive notice. 193

The time is now ripe for the United States Supreme Court to act. The defendant can attack cognovit consent generally. Even if this fails, the argu-

denying defendant's plea that consent did not give F1 jurisdiction, the court stressed the fact that the defendant had had notice. See also McCrairy v. Ware, 6 Kan. App. 155, 51 Pac. 293 (1897).

190 Developments in the Law-State Court Jurisdiction, 73 HARV, L. REv. 909, 944 (1960).

191 See cases cited notes 182 \& 184 supra.

192 At least notice would prevent the courts from having to have a liberal and embarrassing policy of reopening judgments to allow defenses. See note 126 supra and accompanying text. The Maryland practice of requiring notice after judgment, MD. CODE ANN. GEN. RULES OF Pr. AND Proc., RULE 645 (1957), and the new Illinois provision requiring a trial de novo with notice prior to using a cognovit judgment as a basis for a "deduction order," ILL. REV. STAT. ch. $62 \S 82$ (1961), are better than nothing. In Pennsylvania many judgments are entered the day after the money is loaned in order to establish a lien on the borrower's real estate. The judgment is a substitute for a mortgage. See Note, 102 U. PA. L. REV. 524 (1954). If the defendant understands that he is borrowing money on his real estate and giving, as security, an immediate judgment lien, he has notice that the suit will be filed the next day. He could come in and defend. While such a device might be opposed by experts in securities, it might not violate due process.

${ }^{193}$ A justification for cognovit consent is based on the idea that the attorney acts as the agent for the defendant. But this attorney can no more be considered the "agent" of the defendant than could the trustee be considered the "caretaker" in Mullane v. Central Hanover Bank \& Trust Co., 339 U.S. 306, 316 (1950). 
ments 194 will help set the stage for a convincing appeal that the presumption is now against a defendant waiving his due process notice in an adhesion contract. The burden should be on the industry to show why it need take a judgment without notice. If no commercial reason is given, the court should be free to find a violation of due process. With such a holding, the anomaly of the cognovit clause-the procedure which allows judgment without noticewould be laid to rest.

\section{Full Faith and Credit}

The second pesky problem facing the courts concerns the effect to be given to a cognovit judgment obtained in Fl, when the attorney for the finance industry seeks to use his F1 judgment to obtain a new judgment in F2. As pointed out in the section on Traditional Wisdom, F2 courts have reacted in a wide variety of ways to defendants' claims that $F 2$ need not give full faith and credit to an F1 cognovit judgment.

Although the actual number of cases decided by the United States Supreme Court delineating the extent of the full faith and credit clause are not as numerous as might be desired, the conflicts professors have worked out the bulk of the "proper" rules. 195 There are many requirements and defenses to the full faith and credit clause, 196 but lack of jurisdiction in the F1 court is the major and most profitable way of avoiding it. The word "jurisdiction" is ambiguous and encompasses several different ideas, 197 but here includes only the concept that the court rendering the judgment must be competent, i.e., authorized by local law to render this class of judgment; and the court must have control over the person against whom the judgment is directed. In cases where the jurisdiction of the F1 court is based on some other contact than consent, the United States Supreme Court has now settled that F2 need not give full faith and credit to an F1 judgment when the F1 court lacked in personam jurisdiction over the defendant. ${ }^{198}$

194 See text following note 163 supra.

195 See, e.g., EHRENZWEIG §§ 45-92; Paulsen, Enforcing the Money Judgment of a Sister State, 42 Iowa L. REv. 202 (1957); Sumner, Full Faith and Credit for Judicial Proceedings, 2 U.C.L.A.L. REV. 441 (1955).

196 That the decision must be on the merits; that it must be a final decision; that the F2 statute of limitations must not have run; that there must not be payment, release, accord and satisfaction; and perhaps that there be no fraud nor the judgment be on a penalty. See authorities cited note 195 supra for a thorough review of the requirements and defenses.

197 See Restatement (SECOND), Conflict of Laws, Ch. 4, Introductory Note 37 (Tent. Draft No. 3, 1956).

198 Actually there is little "real" authority for this proposition. The texts and article writers cite Thompson v. Whitman, 85 U.S. (18 Wall.) 457 (1874), but it did not concern in personam jurisdiction. The language in Hanson v. Denckla, 357 U.S. 235, 255 (1958), comes the closest. However, in those cases where the Court finds F1 to have had in personam jurisdiction, see, e.g., Milliken v. Meyer, 311 U.S. 457 (1940), Adam v. Saenger, 303 U.S. 59 (1938), the Court leaves no doubt that lack of such jurisdiction would be grounds for F2 to deny full faith and credit. 
In showing lack of jurisdiction, a defendant actually may show several different things: (1) that the law of F1 does not authorize this particular method of acquiring jurisdiction; (2) that what the defendant has done does not fall within the law; (3) that the jurisdictional law of F1 does not meet constitutional due process. 199 The due process attack may be divided into two parts: (1) that the basis of in personam jurisdiction-domicile, "doing business," consent, or other contact-does not meet the minimum required under the fourteenth amendment, and (2) that the notice required by F1 law does not meet the fourteenth amendment's minimum standard. 200

Some intriguing problems arise in applying these principles to in personam jurisdiction based on a cognovit clause. The defendant could, of course, argue the third requirement that the F1 law allowing in personam jurisdiction by consent violated due process either because consent, under the circumstance, was not a reasonable contact or because notice was non-existent. This argument is the same as that made by the defendant in the F1 court discussed above. The argument need not be repeated here. But the defendant might fare better on the state court level making this attack in F2; especially if F2 had a strong policy against the use of cognovits!

If this proves unsuccessful, the defendant may return to the first requirement and claim that the law of F1 does not provide for confession of judgments or for this particular type of confession judgment. In Adam v. Saenger201 the United States Supreme Court made clear that the interpretation of the jurisdictional law of F1, if not litigated there, may be litigated in F2. And since, said the Court, the same full faith and credit shall be given to the $F 1$ proceedings "as they have by law or usage" of that state, the federal right turns on the meaning of the F1 statute. 202 In Adam the F1 statute was clearly jurisdictional

199 Professor Sumner lists four grounds: (1) Authorization for the exercise of power; (2) Constitutional contact of the defendant with the state; (3) Due process notice; and (4) "[F]acts to sustain these prerequisites." Sumner, Full Faith and Credit for Judicial Proceedings, 2 U.C.L.A.L. REv. 441, 453 (1955). He cites McDonald v. Mabee, 243 U.S. 90 (1917) and Milliken v. Meyer, 311 U.S. 457 (1940), as showing these requirements. Id. at 453 n.55. Paulsen lists only two grounds: (1) Fl local law giving the court power to act and (2) the meeting of constitutional standard in the granting of the power. Paulsen, Enforcing the Money Judgment of a Sister State, 42 IowA L. REv. 202, 208 (1957). He cites, generally, Thompson v. Whitman, 85 U.S. (18 Wall.) 457 (1873). All three classifications are basically the same.

200 See cases cited notes $3,9 \& 10$ supra and accompanying text (minimum contact) and notes 182 \& 184 supra and accompanying text (due process notice) for a discussion of the standards.

201303 U.S. 59 (1938).

202 Id. at 64. The "law and usage" language comes from the statute implementing the full faith and credit clause. 62 Stat. 947 (1948), 28 U.S.C. \$ 1738 (1958). The Court also pointed out that it is free to independently determine the $F 1$ law, since it has as much competence as the F2 court. In Hanson v. Denckla, 357 U.S. 235 (1958), the Court used the right of $F 2$ to examine the law of $F 1$ to sustain a Delaware court in refusing to grant full faith and credit to a Florida judgment. The Court found that Florida did not have in per- 
in nature. However, as pointed out by both Professors Paulsen 203 and Leflar, ${ }^{204}$ many errors of procedure may exist in an Fl judgment which may or may not render the $F 1$ judgment void and subject to collateral attack in F1 even though the Fl court has "jurisdiction" in the interstate sense. 205 It is not clear whether F2 may use these defects under the "law or usage" language. Since the defendant may go to $F 1$ and attack the judgment and since judgments may be opened in Fl on a broad range of grounds, Professor Paulsen recommends not allowing F2 to re-examine.206

While entertaining the same worries as Professor Paulsen, Professor Leflar feels $F 2$ should be allowed to check. 107 "[O]therwise a judgment invalid where rendered would be valid and enforceable everywhere else." 208

There is a rather surprising lack of reliance on the first requirement by $F 2$ courts in cognovit cases. 209 The reason is unknown, but perhaps it is difficult for them to show what voids an $\mathrm{Fl}$ judgment in $\mathrm{Fl}$ or perhaps it is the re-

sonam jurisdiction over one defendant. Since under Florida law, this defendant was "an indispensable party," the F2 court did not have to give full faith and credit to any part of the judgment. (1957).

203 Paulsen, Enforcing the Money Judgment of a Sister State, 42 IowA L. Rev. 202, 204-06

204 LEFLAR $\$ 75$.

205 See generally Comment, 66 YALE L.J. 526 (1957).

205 Paulsen, supra note 203, at 206. The leading English case of Pemberton v. Hughes [1899] Ch. 781, takes this view as does the Restatement, Conflict of LAws $\$ 432$ (1934). Paulsen, supra note 203, at 206 n.20, cites Barnes v. Hilton, 172 Kan. 345, 239 P.2d 966 (1952), as employing his suggestion. There, the Kansas Supreme Court gave full faith and credit to a California cognovit judgment when the defendant argued that the lack of an affidavit rendered the judgment void. The court pointed out that the defendant could try to set aside the California judgment. This the defendant did. Barnes v. Hilton, $118 \mathrm{Cal}$. App. 2d 108, 257 P.2d 98 (1953). Paulsen suggested that Kansas would subsequently vacate its own judgment. Although partially due to procedural difficulties, it did not! Barnes v. Hilton, 178 Kan. 645, 290 P.2d 1024 (1955). See Restatement (Second), Conflict of Laws \$ 81, Comment $d$ (Tent. Draft No. 3, 1956).

207 LEFLAR $\$ 75$.

208 Id. at 144.

${ }^{209}$ See cases cited note 144 supra. A classic example of a successful attack occurred in Wilensky v. Miller, 257 Wis. 589,44 N.W.2d 521 (1950). There the Wisconsin court refused, after citing Illinois cases, to grant full faith and credit to a judgment obtained against a joint maker of a cognovit when the other maker, a corporation, had been dissolved. The Wisconsin court found that under Illinois law an Illinois court had no power to enter judgment under such circumstances. An excellent illustration of the variety of approaches can be seen in comparing First Nat'l Bank v. Cunningham, 48 Fed. 510 (D. Ky. 1891), Bower v. Casanave, 44 F. Supp. 501 (S.D.N.Y. 1941), and Hazel v. Jacobs, 78 N.J.L. 459, 75 Atl. 903 (Ct. Err. \& App. 1910). In Cunningham, supra, the court pointed out that under Illino1s law, prior payment of the note extinguished the cognovit and rendered the judgment void. In Bower, supra, the court was quite willing to check F1 law, but found that under Illinois law prior payment allowed only a collateral attack, consequently a defense of payment would be relitigating the merits. In Hazel, supra, the court did not check F1 (Delaware). It merely held that the question of prior payment went to the merits and could not be raised in F2. 
luctance of $F 2$ courts to give a broad interpretation to "law and usage."210

Most often a defendant, in the cognovit area, will attempt to argue, even though he may not realize it, the second reason for "lack of jurisdiction," i.e., that the facts 211 do not justify the use of the consent statutes of F1 since consent was not in fact given. It is here that the peculiar nature of cognovit clauses comes into play. There are several different ways a defendant might attempt to show the "lack of consent." A very few cases illustrate what might be designated as "true fact" cases, i.e., that the defendant did not sign the note, 212 that the cognovit clause was forged,213 that the contract containing the cognovit was rescinded for fraud,214 or that the defendant was not authorized to sign the cognovit.215

Then there are those cases which on the surface can be and normally are classified as fact cases, but which actually present a mixture of "lack of fact" and "lack of law" since, in one sense at least, the "lack of fact" is due to the non-operation of some legal rule. The only two United States Supreme Court cases on cognovit clauses illustrate this problem.216 In National Exch. Bank v. Wiley, ${ }^{217}$ the Court held that Nebraska did not have to give full faith and credit to an Ohio judgment since the Nebraska jury found that the plaintiff was not actually the "holder" of the note, ${ }^{218}$ and the cognovit clause authorized only the "holder" to acquire jurisdiction. The Court, after a thorough review of the Ohio cases, admitted that an Ohio court would probably find the plaintiff a "holder." Yet the Court, citing old textbooks on bills and notes, ${ }^{219}$ argued that one not the owner of the note could not "in law" be the holder. The Court then cited221 Thompson $v$. Whitman,222 and said that since

210 See authorities cited in notes 203 \& 204 supra. On the right to collaterally attack in F1, see generally Comment, 66 YALE L. J. 526 (1957).

211 A good example of a "fact" case not involving cognovits is American Cas. Co. v. Kincade, 219 Miss. 653, 69 So. 2d 820 (1954)(defendant not doing business in F1).

212 First Nat'l Bank v. Brown, 119 Fla. 761, 162 So. 142 (1935).

213 Anderson v. Reconstruction Fin. Corp., 281 Ky. 531, 136 S.W.2d 741 (1940).

214 Brone v. Golde, 267 N.Y. 284, 196 N.E. 58 (1935).

215 Monarch R'efrigerating Co. v. Farmers' Peanut Co., 74 F.2d 790 (4th Cir. 1935) (defendants allowed to show, by answer, that the officers of the corporation were in fact not authorized).

216 National Exch. Bank v. Wiley, 195 U.S. 257 (1904); Grover \& Baker Mach. Co. v. Radcliffe, 137 U.S. 287 (1890).

217195 U.S. 257 (1904).

218 The plaintiff had apparently assigned the note to a third party who had returned it to the plaintiff for the purposes of suit. Any monies collected would have gone to the third party.

219 Id. at 268. The court cited Byies on Bills and 1 Parsons, Bills and Notes.

220 Ibid.

221 Id. at 269.

22285 U.S. (18 Wall.) 457 (1873). 
there was no authority for the plaintiff to take the confession, Nebraska did not have to give full faith and credit. "It [the judgment] was in such case, in legal effect, a personal judgment without service of process upon the defendants and without their appearance in person or by an authorized attorney. The proceedings were wanting in due process of law."223

Earlier, in Grover \& Baker Mach. Co. v. Radcliffe,224 the Court found that a Pennsylvania judgment entered against the defendant by a prothonotary was not binding on the Maryland court since the defendant in the cognovit clause had authorized only an attorney to confess judgment. The Court said that since the defendant did not "actually" consent, Maryland did not have to recognize the Pennsylvania judgment. There was no in personam jurisdiction.

But the plaintiff showed, and the Court admitted, that the use of a prothonotary without the attorney confessing judgment followed the law and practice of Pennsylvania. The Court for a second reason relied on an argument of the defendant that since he could not know the laws of all the states where the plaintiff might enter judgment, he had not, in fact, consented to rules of law that created his consent in this fashion.

The Court also stated that Maryland was free to attack even though the Pennsylvania judgment was valid in Pennsylvania. The Court said: "[T] hat, in this respect [the right to attack jurisdiction of an F1 court], a court of another state is to be regarded as a foreign Court. ..."225

These two cases are used by F2 courts226 to justify giving a "strict construction" to the cognovit. If the F2 court finds that by some "law," usually their own or by the law of the place of making or some other contact, the consent was not in fact given, F1 had no jurisdiction.

Two questions arise. What type of "strict construction" did these two cases allow to an F2 court, and would the Supreme Court continue to follow these cases today?

In the Grover case, the Court bottomed its decision on three grounds: (1) that the cognovit used only the word "attorney" so no "actual" consent was given to a prothonotary; (2) that since the defendant did not know where judgment would be entered, he had not consented to an interpretation that an attorney included a prothonotary, i.e., lack of legislative jurisdiction; and (3) that F2 may treat an F1 judgment as an extra-national judgment on jurisdictional questions. In National Exch. Bank the Court talked, in

223195 U.S. at 270.

224137 U.S. 287, 298 (1890).

225 Id. at 294.

226 See cases cited note 143 supra. But see Greenbaum \& Sons Bank \& Trust Co. v. Porth, 116 Kan. 310, 226 Pac. 747 (1924), where the Kansas Supreme Court, in answer to a defendant's claim that the plaintiff was not the holder, said: "[T] was the holder of the notes, and the court by its judgment necessarily so found . . . " Id. at 314,226 Pac. at 749. However, the court might have allowed the defendant to prove that in "fact" the plaintiff was not the "holder." Id. at 314, 226 Pac. at 749. 
places, 227 as if Ohio's interpretation of the word "holder" violated due process. Actually the Court only held that to enter judgment without consent violates due process. The lack of consent arose, reasoned the Court, since "in law" a non-owner of a note may not be the holder.228 Surely these cases grant a large measure of freedom to $F 1$ to use any law to find no consent.

Which, if any, of these freedoms will the Court still follow today? By 1961 it is extremely doubtful that the Court would still treat a sister state judgment in the same manner as an extra-national judgment. The great drive toward full faith and credit 229 now blurs any distinction between local due process jurisdiction and interstate jurisdiction. If the FI court would find jurisdiction and if that finding does not violate due process, F2 must give full faith and credit. 230

The view in National Exch. Bank and Grover that the F2 court has freedom to find that no consent was in fact given since, tested by some "proper" or some super law, the cognovit cannot be interpreted to give the consent, will probably no longer stand up. Cases like Adam v. Saenger 231 certainly imply that full faith and credit must be given if the $F 1$ court correctly applied its own statutory and case law and if that law was constitutional. In Adam, the Court examined the California law and found "that the service in the California suit was authorized by California law." 232 It is true that Adam explicitly concerned a jurisdictional statute and not the existence of a "fact." But the breadth of the

227 "If law and usage in Ohio were to the contrary, then, such law and usage would be in conflict with the Constitution...."195 U.S. at 269.

228 The "in law" language seems strange today. However, National Exch. Bank was decided prior to Erie R.R. v. Tompkins, 304 U.S. 64 (1938). There was still a federal "common law."

229 See, e.g., Morris v. Jones, 329 U.S. 545 (1946); Milliken v. Meyer, 311 U.S. 457 (1940); Adam v. Saenger, 303 U.S. 59 (1938); Milwaukee County v. M.E. White Co., 296 U.S. 268 (1935); Yarborough v. Yarborough, 290 U.S. 202 (1933); Fauntleroy v. Lum, 210 U.S. 230 (1908).

230 While interstate divorce jurisdiction may be an exception to this unity, the United States Supreme Court, when squarely faced with the issue, avoided it in a split decision. Granville-Smith v. Granville-Smith, 349 U.S. 1 (1955). Professor Ehrenzweig suggests that as to extranational judgments, F2 courts will retain this right to examine jurisdiction under the law and policy of the F2 court, but as to sister-state judgments, there now is the "identity or near-identity" of local and interstate jurisdiction. EHRENZWEIG \$ 57, at 203. Yet in writing of in personam jurisdiction, he states that the plaintiff may attack F1 jurisdiction over the person "although that court [F1] may have found to the contrary." Id. at 205. Professor Sumner states: "[i]t should be noted that if the basis of judicial jurisdiction of the first state is valid under the Due Process Clause, it is immaterial whether it would be sufficient to support a judgment in the second state, and due respect must be given." Sumner, Full Faith and Credit for Judicial Proceedings, 2 U.C.L.A.L. Rev. 441, 454 (1955).

231303 U.S. 59 (1938).

232 Id. at 67. Cf. Titus v. Wallick, 306 U.S. 282 (1939), where the Court examines F1 law to determine if the plaintiff was entitled to bring the suit in F1. 
consent becomes jurisdictional. If by the "law and usage"233 of F1, it would find in "fact" that the consent existed234 and if that "law" does not violate due process, $F 2$ surely must give full faith and credit. 235

The third basis for the judgment in Grover, that the defendant could not have been deemed to have consented to the law and practice of Pennsylvania since he could not reasonably be expected to have knowledge of that law or that the plaintiff would take judgment there, undoubtedly is still valid since it adjudicates the constitutionality of the F1 law as applied. The United States Supreme Court has seldom spoken on "legislative jurisdiction,"236 but other courts have used it to find that a defendant had not consented to the "laws" of a foreign state.237 The new Restatement recognizes "legislative jurisdiction"238 and applies to it the same test of reasonableness as it does to judicial jurisdiction. Consent is reasonable, 239 but if, on the facts, the defendant cannot reasonably be said to have consented to the legislative jurisdiction of F1, the application of Fl's law would violate due process. Consequently, the F1 judgment would be void. Therefore, in the situation where the "fact" of consent turns on the legal meaning of the language of the cognovit, the F2 court may construe, but must use, FI's law. Only when the application of the F1 law would violate due process 240 could $F 2$ refuse to use the $F 1$ law.241

233 "Such . . . judicial proceedings ... . shall have the same full faith and credit in every court ... as they have by law or usage in the courts ... from which they are taken." 62 Stat. 947 (1948), 28 U.S.C. \$ 1738 (1958).

234 In Williams v. North Carolina, 325 U.S. 226 (1945), the Court allowed a North Carolina jury to find that the defendant was not in fact domiciled in Nevada, but the finding of the Nevada court was entitled to prima facie weight. This right to attack the "facts" exists for jurisdiction based on consent. But in Williams, the Court does not say that North Carolina may use a different definition of domicile from that of Nevada. The Court points out that the case involves "an historic notion common to all English-speaking courts, that of domicil ...." Id. at 234. Moreover, in this case, the F1 law of domicile would have to follow the United States Supreme Court's formulation in order for Nevada to have had interstate jurisdiction.

235 The Supreme Court's interpretation of the extent to which res judicata can be used to foreclose jurisdictional questions offers another example of the importance of the "law and usage" language. In Johnson v. Muelberger, 340 U.S. 581 (1951), the Court held that INew York must follow Florida's law on the extent to which res judicata bound third parties. See EHRENZWEIG $\S 66$ for further examples of F1's law controlling.

236 Cf. Skiriotes v. Florida, 313 U.S. 69 (1941) on legislative jurisdiction in the criminal law. Note also Thomas v. Matthiessen, 232 U.S. 221 (1914), where the Court finds that the defendants had shown that they were consenting to California law.

237 See, e.g., Pope v. Heckscher, 266 N.Y. 114, 194 N.E. 53 (1934); Copin v. Adamson, L. R. 9 Ex. 345 (1874).

238 Restatement (SECOND), Conflict of Laws § 43e-f (Tent. Draft No. 3, 1956).

239 Id. at $\$ 43 \mathrm{f}(1)(\mathrm{d})$ and comment $g$.

240 As pointed out in the text, the application of $F 1$ law would violate due process if $F 1$ lacked legislative jurisdiction. It is also conceivable that even though $F 1$ had legislative jurisdiction, the F1 law itself was so removed from reality that the application of the F1 law to find the "fact" of consent would violate due process. 
Another reason for an F2 court to refuse to follow F1's valid cognovit procedure is raised by Professor Ehrenzweig. In his book on conflicts he has a section labeled "Requirements of Recognition: Judgments; 3. Proper Procurement, and Unfair Procedure."242 He says that a difference in procedure, unless it violates due process, is generally considered not a reason for refusing to uphold the F1 judgment. ${ }^{243}$ But he then suggests that cognovits "disturb the accuracy of this observation," 244 since some courts have refused recognition to cognovit judgments. He argues, however, that Fauntleroy v. Lum, 24s "with its rigid standards of full faith and credit," 246 prohibits F2 from refusing to give full faith and credit on the grounds that $\mathrm{Fl}$ 's public policy is violated. Certainly public policy on substantive matters is no longer a valid ground for refusing recognition. Likewise as long as Fl's procedure does not violate due process, F2 may not use its public policy to object to F1 using whatever procedure it likes. 247

Frequently the defendant will argue and the F2 court will use still another technique to deny jurisdiction to $F 1$ courts. This device is also an admixture of jurisdictional fact and law, but differs as to the active ingredient. Before, the court found that, by applying some law, a particular consent was not broad enough to grant power to the F1 court. There was no "actual" consent to this particular judgment. Under this later technique there is no question that the consent was given and that it would, if effective, cover the F1 judgment. Rather the court finds that by the operation of some law no consent exists. The actual consent is rendered legally void. The classic situation involves the cognovit clause executed in an F2 state which prohibits its execution or use. The note with the cognovit is then sent to a finance company in F1 where the company subsequently enters judgment, using the cognovit as the basis of jurisdiction. The finance company then seeks to enforce its F1 judgment in F2. The F2 courts 248 approach this problem as one of finding the "proper

241 This same argument applies to the right of F2 to ignore F1's choice of law rule. It may do so only when Fl's choice is invalid because it violates due process or full faith and credit. See note 265 infra and accompanying text.

242 EHRENŹwEIG $\$ 55$.

243 Id. at 196.

244 Ibid.

245310 U.S. 230 (1908).

246 EHRENZWEIG § 55, at 197.

247 Courts have not attempted to use "public policy" to any great extent. When all of the operative facts occur in $F 1$ and no one raises any problems concerning the jurisdiction of the F1 court under F1 law, F2 courts have been quite willing to grant full faith and credit to the F1 judgment despite the fact that $F 2$ would not take original jurisdiction under the cognovit clause. See cases cited note 145 supra. When the court wishes to give effect to its local policy on cognovits it uses other, frequently erroneous, devices to withhold recognition. Professor Ehrenzweig suggests that the fact that a minority of states deny recognition in violation of the full faith and credit clause attests to the strength of the local policy. Ehrenzweig, Contracts in the Conflict of Laws-Part One: Validity, 59 ColuM. L. Rev. 973, 1020 (1959).

248 See notes 146 to 156 supra and accompanying text. 
law" to govern the cognovit clause. If an independent determination by F2 discloses that the "proper law" renders the contract illegal, F2 finds the contract and the consent void. A void consent cannot give jurisdiction to an F1 court, the F2 court concludes.

Patently, F2's right to attack the jurisdiction should not, today, extend this far. As shown above, 249 the law of F1, not that of F2, determines the jurisdiction of the Fl courts. Here, of course, the jurisdictional law in question is the choice of law rule of Fl. If Fl's choice of law rule refers either to its own law or to any law rendering the consent valid, then F1 does have jurisdiction and F2 must give full faith and credit. This proposition was early recognized in a student note in the Yale Law Journal.250 Professor Ehrenzweig apparently takes the view, 251 and Professor Paulsen 252 explicitly says that Fl's rule is jurisdictional.253 But no case has been found in which an F2 court felt bound to examine FI's choice of law rule. 254

Even if the F2 court must follow the F1's choice, it still has available all of the usual methods of attacking jurisdiction. Since the legal existence of jurisdiction, here consent, depends upon the F1 choice of law rule and its constitutionality, the F2 court has the opportunity to repeat its analysis of the jurisdiction of the F1 courts. As discussed above2ss the F2 court may check: (1) whether the law of $\mathrm{Fl}$ gives Fl's courts jurisdiction, i.e., the choice of law

249 See note 231 supra and accompanying text.

250 Comment, Due Process and The Full Faith and Credit Clause, 34 YALE L.J. 886 (1925). The student criticizes Egley v. T.B. Bennett \& Co., 196 Ind. 50, 145 N.E. 830 (1924). In Egley the F2 court treated the choice of law problem as if it had the right to determine the "proper law" governing the cognovit. The court arrived at the apparently proper result by finding the F1 law governed. But the vice of the Egley "proper law" approach is in the fact that other F2 courts have a different choice of law rule. Consequently the "proper law" approach allows F2's choice of law policy to be decisive. If local public policy is not a valid ground for denying recognition, choice of law policy should fare no better.

251 EHREN2WEIG \$ 5S. He suggests that Fauntleroy v. Lum, 210 U.S. 230 (1908), prevents $F 2$ from finding "inapplicable the law of the rendering court. ..." Id. at 197. The "law" is apparently choice of law from the cases he cites.

252 Paulsen, Enforcing the Money Judgment of a Sister State, 42 IowA L. REV. 202, 209-11 (1957).

253 However, after he correctly suggests that F2 may challenge the zonstitutionality of the F1 choice of law rule, he leaves somewhat open the question of F2's right to find a different choice of law rule from that used by F1. In one example, id. at 210 , he says F1's rule governs. Later, id. at 211, while suggesting that F2 may challenge the constitutionality of the F1 rule, he cites cases, e.g., Monarch Refrigerating Co. v. Faulk, 228 Ala. 554, 155 So. 74 (1934), where the F2 court did not raise the constitutional issue, but merely used their own choice of law rule. Earlier he says that F2 will give full faith and credit when "defendant's consent is validly given by the note (tested by the law governing the undertaking) . . . ." Id. at 209 n.35. (Emphasis added.)

254 In Pearson v. Friedman, 112 So. $2 d 894$ (Fla. Dist. Ct. App. 1959), the court cites F1 choice of law rules as being in accord with the F2 rule and "the prevailing conflict of laws rule." Id. at 895.

255 See note 199 supra. 
rule of F1 refers to a law rendering the consent valid, (2) whether the facts justify the application of this choice of law rule, and (3) whether the law is unconstitutional. However, this time the "law" is the choice of law rule, not the local rule allowing the use of cognovits.

To find the choice of law rule of F1 presents an unusually difficult task for the F2 court. 256 "Contracts is by common consent the most complex and also the most confused part of conflict of laws."257 Frequently one state will use, simultaneously, different contact points. 258 Consequently, general rules for contract choice of law frequently mean little. With the new Restatement's chapter on contract choice of law259 and with the massive and basic attacks on traditional choice of law thinking in contract and other areas, 260 there is little reason to assume that existing choice of law rules will remain constant.

Theoretically $F 2$ should see if $F 1$ has decided what contact points are important when, in an adhesion contract, the borrower signed the contract in a sister state; the lender was domiciled in and accepted the contract in $\mathrm{Fl}$; and the agreement provided that the law of F1 was to govern. ${ }^{261}$ But the confusion surrounding almost all $F 1$ 's choice of law rules ${ }^{262}$ would seemingly allow, as a

256 Or for the attorney that has the burden of showing lack of jurisdiction in F1. As Ehrenzweig points out, EHRENzwEIG $\$ 57$ at $205, \S 59$ at 211 , the plaintiff may have the burden of showing that the local law of $\mathrm{F} 1$ does provide for this type of jurisdiction. See cases cited note 135 supra.

257 Restatement (SeCOND), Confict of Laws, Ch. 8, Contracts, Introductory Note at 1 (Tent. Draft No. 6, 1960).

258 See, e.g., Jones v. Metropolitan Life Ins. Co., 158 Misc. 466, 286 N.Y.S. 4 (App. T. 1936). 1960).

259 Restatement (Second), Conflict of Laws, Ch. 8, Contracts (Tent. Draft No. 6,

260 Professor Currie's articles, e.g., The Verdict of Quiescent Years: Mr. Hill and the Confict of Laws, 28 U. CHI. L. REV. 258 (1961), Currie, Notes on Methods and Objectives in Conflict of Laws, 1959 Duke L. J. 171, Currie, Married Women's Contracts: A Study in Conflict-of-Laws Method, 25 U. CHI. L. REv. 227 (1958), have occasioned the most comment. See, e.g., Hill, Governmental Interest and Conflict of Laws-A Reply to Professor Currie, 27 U. CHI. L. Rev. 463 (1960); Sumner, Choice of Law Rules: Deceased or Revised?, 7 U.C.L.A.L. REy. 1 (1960). Professor Ehrenzweig has been busy. See, e.g., Ehrenzweig, Choice of Law: Current Doctrine and "True Rules," 49 CALIF. L. Rev. 240 (1961); Ehrenzweig, Contracts in the Conflict of Laws (pts. 1-2), 59 Colum. L. Rev.973, 1171 (1959). As has Professor Weintraub. See, e.g., Weintraub, The Contracts Proposals of the Second Restatement of Conficts of Laws-A Critique, 46 IOWA L. REv. 713 (1961); Weintraub, A Method for Solving Conflict Problems, 21 U. PITr. L. REv. 573 (1960).

261 Most of the form contracts furnished by the attorneys for the industry contain a clause designating the law of a particular state to control the contract.

262 A hasty perusal of the choice of law rules of Illinois, a popular cognovit state, shows the difficulty facing an F2 court. The Florida District Court of Appeals in Pearson v. Friedman, 112 So. $2 d 894$ (1959), could cite only three Illinois cases: Burr v. Beckler, 264 ill. 230, 106 N.E. 206 (1914); Forsyth v. Barnes, 228 Ill. 326, 81 N.E. 1028 (1907); Barrow v. Phillips, 250 III. App. 587 (1928). Burr v. Beckler, supra, did not involve a cognovit clause. The court found that the law of the place where a note was delivered by depositing in the mail controlled and therefore the contract of the defendant, a married woman, was void. In Forsyth, 
practical matter, great freedom to the $F 2$ court. F2 will undoubtedly exercise this freedom, although the United States Supreme Court will sit in review of

supra, the court refused to give full faith and credit to an Ohio judgment on the grounds that jurisdiction was obtained by a cognovit clause signed by a married woman in Ohio and payable in that state. The court assumed the common law prevailed in Ohio and found that a married woman's contract was void. Therefore there was no consent. In Barrow, supra, the Illinois court opened up its own cognovit judgment on the grounds that the note was physically delivered in Florida and the rule of Forsyth controlled. But the Florida court did not cite Davis v. Wirth, 249 Ill. App. 544 (1928), and Davis v. Mosbacher, 252 Ill. App. 536 (1928). In these cases, involving the same facts and parties, the court in refusing to open their own cognovit judgment, pointed out that, although the defendant claimed that the note was a Missouri contract, the declaration averred that it was delivered in Illinois and that the place of delivery, not the place where the note was written, signed or dated, determined the place of making. An Illinois attorney, in 1945, commented that a review of all the choice of law contract cases suggested that the Illinois court would follow the expressed or presumed intention of the parties. Bernhard, A Rationalization of the Illinois Confict of Laws Rules Applicable to Contracts, 40 ILL. L. REv. 165 (1945).

The Illinois statute allowing cognovits may contain a choice of law rule in the form of an apparent venue requirement. The statute provides: "[T] ment . . . shall be made in the county in which the note ... was executed or ... in which one or more of the defendants reside or ... in which is located any property . . . owned . . . by the defendants. A judgment entered by any court in any county other than those herein specified has no force or validity, anything in the power to confess to the contrary notwithstanding." Ilz. Rev. SraT. ch. 110, § 50(4) (1959). (Emphasis added.) The venue statute, itself, provides: "No ... judgment . . . is void because rendered in the wrong venue, except in case of judgment by confession as provided in section 50(4) . . . " III. REV. STAT. ch. 110, $88(1)$ (1959). The exception for confession judgments was added in the general revision of the civil practice code in 1955. Ill. Laws 1955, § 8(1), at 2241. In Wlodek v. Sedlacek, 30 Ill. App. 2d 351,174 N.E.2d 705 (1961), the court held, in a syllabus opinion, that a cognovit judgment should be vacated since the trial court had no jurisdiction and the judgment was void when none of the three statutory requirements-execution, residence, or property-occurred in the county.

Although the Municipal Court of Chicago, in which most cognovit judgments are taken, requires, in the printed form used for filing claims on cognovits, that the attorney swear that one of the three venue requirements exist, there is doubt as to whether in the municipal court the venue requirements are jurisdictional. See Mitchell v. Comstock, 305 III. App. 360, 27 N.E.2d 620 (1940). One of the sections of the Code providing for the Municipal Court of Chicago states: "No summons . . . need be issued or served in the case of the confession of a judgment . . . but, such judgment may be confessed in the same manner, as near as may be, as in a similar case in the circuit court." ILL. REV. STAT. ch. 37, § 395 (1959).

Even if the execution of the note in the county of judgment is jurisdictional, the Illinois court has held that the place where the note is dated is presumptively the place of execution. Mitchell v. Comstock, supra. In Turner v. Alton Banking \& Trust Co., 181 F.2d 899 (8th Cir.), cert. denied, 340 U.S. 833, rehearing denied, 340 U.S. 885 (1950), the court, sitting as an F2 court, found, citing Mitchell, supra, that the F1 record was sufficient when it showed that the note was dated in the county where judgment was taken. Turner, supra, however, was decided prior to the 1955 amendment. Although the status of these statutes is unclear, certainly an F2 court might take evidence that a non-resident did not "execute" the note in the county where the judgment was taken and hold that the defect, although appearing in a venue statute, was jurisdictional. Cf. Doherty \& Co. v. Goodman, 294 U.S. 623 (1935).

In Ohio there seems to be little authority. In Albert v. Sitton, 84 Ohio Abs. 414,170 N.E. 2d 925 (C.P. Ct. 1959), the court, despite the fact that the note showed on its face that it was made and payable in Ohio, found that it was actually signed and delivered in Indiana. The 
F2's determinations of F1's choice of law rule. 263

Once F2 has found F1's choice of law rule, it may then proceed to apply the three jurisdictional tests. The first two would seemingly merge together in practice. F1's choice of law rule, in theory at least, explicitly refers to factual contact points. $F 2$ examines $F 1$ 's rule and finds, for instance, that $F 1$ says place of making and that where the note is signed is the place of making. F2 then determines the fact-where was the note signed-and applies the rule, i.e., uses the substantive law of that state. If that state finds cognovits valid, F1 has jurisdiction. Since F1 states do not always refer to their own law, 264 F2 will frequently be free to refuse to give full faith and credit to the F1 judgment.

The third attack available to an F2 court is that the F1 choice of law rule is unconstitutional. Here F2 argues that the United States Supreme Court would find that $F 1$ 's rule violates due process or the full faith and credit to public acts requirement.265 A separate article would be needed to discuss the extent to which the Supreme Court has been willing or might be willing in the future to use either due process or full faith and credit as a means of controlling state

court said, finding no Ohio law in point, that the law of the place of making controlled and, since Indiana prohibited cognovits, the cognovit was void.

The Albert case was decided on May 20,1959. On June 8, 1959, the Ohio legislature amended the provision allowing an attorney to confess judgment to add the phrase: "which shall be in the county where the maker resides or in the county where the maker or any one of several makers signed the warrant of attorney authorizing confession of judgment, any agreement to the contrary notwithstanding." Ohio Laws 1959 , at 137 , now appearing as OHIo REv. CODE ANN. $\S 2323.13$ (Baldwin 1960). Whether the legislature intended to make this amendment jurisdictional is unknown. At least an $F 2$ court could so argue. The amendment was probably passed to combat the practice of Pennsylvania creditors confessing judgment in Ohio to gain advantage of Ohio's more favorable garnishment laws. See text following note 83 supra. At least Ohio's act reads "signed." Illinois' act, supra, only reads "executed."

In Pennsylvania in Krantz v. Kazenstein, $22 \mathrm{~Pa}$. Super. 275 (1903), the court held that the law of the place of payment, which apparently was Pennsylvania, controlled as against the place of dating and execution, New York. No venue restriction appears in the Pennsylvania statute, PA. Stat. ANN. tit. 12, $\$ 739$ (Supp. 1960). For the few cases from other states see Annot., 19 A.L.R.2d 544 (1951).

263 Adam v. Saenger, 303 U.S. 59 (1938). Hanson v. Denckla, 357 U.S. 235 (1958) makes clear that F2 is free to rely on past F1 Supreme Court determinations on the state of F1's law. This should dispel any jurisprudential argument that the trial court, in rendering judgment, necessarily determined the choice of law rule for $\mathrm{Fl}$ and that that choice of law rule pointed to a state substantive law which rendered the cognovit consent valid. Actually in a judgment on confession, the trial court judge, according to Elledge, note 25 supra and accompanying text, merely signs the juogment role at the bottom of each page. He makes no determination of choice of law or anything else.

264 See note 262 supra.

265 This is a separate and distinct due process argument from that used at the start of the section. There the argument turned on the validity of consent as a jurisdictional basis and the lack of notice. Here it is a question of the validity of the choice of law rule. See generally authorities note 266 infra. 
choice of law rules. The topic is current and many law professors are arguing the relative merits of Supreme Court dominance. ${ }^{266}$ The Supreme Court itself is gun shy267 and has in recent years generally backed off.268 There is no indication that the Court will seek to establish a detailed control. As long as F1 has sufficient contact with the transaction to make it "reasonable" to apply its own law,269 the Supreme Court would not find such a choice in violation of due process. 270 Any contact point that would sustain in personam jurisdiction should be sufficient for choice of law. If all F1 needs is one contact point, or a "governmental interest,"271 F2 will find it difficult to refuse the F1 judgment on this ground. Surely, in almost all cases, F1 will be the domicile of the lender or the place of payment.272 It is remotely conceivable that F1 might choose a sister state's substantive law to validate the consent when that state had no contact or interest in the transaction. In this unlikely event, Fl's choice

266 See, e.8., EHRENZwEIG §9; Currie, The Constitution and the "Transitory" Cause of Action (pts. 1-2), 73 HARV. L. REv. 36, 268 (1959); Currie, The Constitution and the Choice of Law: Governmental Interests and the Judicial Function, 26 U. CHr. L. REV. 9 (1958); Weintraub, Due Process and Full Faith and Credit Limitations on a State's Choice of Law, 44 LowA L. REV. 449 (1959). Other clauses of the U.S. Constitution may limit state action. See Currie \& Schreter, Unconstitutional Discriminations in the Confict of Laws: Equal Protection, 28 U. CHI. L. REv. 1 (1960); Currie \& Schreter, Unconstitutional Discrimination and the Confict of Laws: Privileges and Immunities, 69 YALE L.J. 1323 (1960).

267 Clay v. Sun Ins. Office Ltd., 363 U.S. 207 (1960).

268 See EHRENZWEIG §9.

269 If $\mathrm{F} 1$ does apply its own law it is, in effect, adopting a choice of law rule that points to $\mathrm{Fl}$.

270 An early note on cognovits, Note, Due Process and the Full Faith and Credit Clause, 34 YALE L.J. 886 (1925), suggested that if the F1 choice of law rule was "reasonable," it would not violate due process. Apparently reasonableness should be tested by whether F1 was a contact point. Professor Paulsen points out, Paulsen, Enforcing the Money Judgment of a Sister State, 42 Iowa L. REV. 202 (1957), that if F1 has no contact point, the use of its own law would violate due process. He cites Home Ins. Co. v. Dick, 281 U.S. 397 (1930). Id. at 210 n.38. Professor Currie would, apparently, test "reasonableness" in terms of "governmental interest." Under such a view, the existence of a contact point would not be controlling. Currie, The Constitution and the Choice of Law: Governmental Interests and the Judicial Function, 26 U. CHI. L. REv. 9 (1958). However, FI could not claim the right to use its own law merely because cognovits concern local procedure. See Curric, supra at 44.

Note also that this argument is basically the same as used by the Supreme Court in Grover \& Baker Mach. Co. v. Radcliffe, 137 U.S. 287 (1890). There the Court found lack of legislative jurisdiction when Pennsylvania attempted to apply its law to interpret the grant of power in the consent. See note 224 supra and accompanying text. Here, however, the contact point is needed for choice of law, not to interpret the grant of power. Yet both defects are grounded on defeating the reasonable expectation of the defendant.

271 See generally Currie, The Constitution and the Choice of Law: Governmental Interests and the Judicial Function, 26 U. CHI. L. REv. 9 (1958).

272 It is conceivable that a lender in a state prohibiting cognovits might establish a practice of taking such judgments to Pennsylvania, obtain his judgment, and then re-sue in his home state. Although there is some evidence of this practice, see text following note 83 supra, the lender could establish a branch office and the place of payment in Pennsylvania. See note 85 supra and accompanying text. 
would probably violate due process. ${ }^{273}$ The Court has, on occasion, demanded that a state give full faith and credit to a particular foreign substantive law; today it is extremely unlikely that it will do so in the cognovit situation. There are no special equities requiring one and only one law to govern. 274

With so little help from the Supreme Court and with the facts in favor of F1, F2 will find the third ground-the unconstitutionality of Fl's choice of law rule - of little help.

This review of the constitutional approaches to F1 cognovit judgments leads to three conclusions. First, F2 courts are wrongly applying the full faith and credit clause. F2 courts are giving full faith and credit to F1 judgments when they are under no obligation to do so.275 They are refusing to give full faith and credit when they should.276 Or they are completely ignoring one whole set of requirements that might or might not require full faith and credit.277 Second, the rules for the proper application of full faith and credit in this area are extremely involved and theoretical. Consequently, most borrower's attorneys will be unable to research and argue the proper rule to the $F 2$ court. Third, the existing confusion allows F2 courts, with relative safety, to manipulate the rules to give effect to their local policy toward cognovit clauses and adhesion contracts. This desire is understandable and probably not condemnable. But it perverts the proper desire of the United States Supreme Court to weld fifty states into one nation through the use of the full faith and credit clause.

\section{CONCLUSION}

The current drive of the United States Supreme Court to increase the right of courts to exercise in personam jurisdiction is commendable. Forum non conveniens should ultimately become the test. But this drive does not serve its function of "balancing the conveniences" when the stay-at-home plaintiff is not the little man. Here the finance company, through use of an adhesion contract and traditional thinking, has been able to take judgment against a nonresident who had but limited contact with the state where judgment was rendered. Yet the Supreme Court would not and probably should not use the balancing test solely in terms of the resources of the respective parties. If a

273 See Currie, The Constitution and the Choice of Law: Governmental Interests and the Judicial Function, 26 U. CH. L. REv. 9, 16 (1958).

274 See articles note 266 supra for a review of the Supreme Court cases.

275 The refusal of F2 to check the local jurisdictional law of F1 is the best example.

276 The narrow construction of the consent when the law of $F 1$ gives a broader construction and has legislative jurisdiction, and the using of an F2 choice of law rule to determine the "proper" law of the consent in order to find it void are the best examples.

277 F2's consistent refusal to check F1's choice of law rule is the example. When F2's rule refers to a state prohibiting cognovits, it will render F1's judgment void. 
little defendant deals with a foreign finance company he has had contact with the foreign state. As long as "contact" is basically the test of "reasonableness," the small defendant is caught.278

A recent West Virginia case illustrates this point and makes another. In Gavenda Bros. v. Elkins Limestone Co.,279 the West Virginia Supreme Court upheld the constitutionality of the broad Illinois jurisdictional statute280 when applied to a non-resident defendant who gave a note for the purchase of merchandise in Illinois. The court found that this was sufficient contact and gave full faith and credit to the judgment. At the end of the opinion, the court observes that the note contained a cognovit clause. The court said: "[T] tiff ... could have obtained a valid judgment by confession ... if it had elected to have obtained jurisdiction in that manner."281

According to the West Virginia court the plaintiff had two equally valid choices. But there is one fundamental difference between the two methods of obtaining jurisdiction. Under the statute, notice is required. Under a cognovit, the defendant waives notice. There can be no valid reason to require notice in the first case and not in the second. Illinois should be able to render judgment in either case only after the defendant has a chance to put in a defense.

Beyond inherent fairness, to require notice would have other beneficial results. First, it would help clean up the full faith and credit mess. The finance industry, already half convinced that cognovits are bad, would turn, at least as to non-residents, to the new Illinois type statute to obtain their jurisdiction.282 F2 courts and borrowers' attorneys are able to handle these statutes under the full faith and credit clause. Second, in addition to protecting the citizens of the three states where cognovits are used for non-notice judgments, it might induce the legislatures of those states to abolish cognovits entirely. 283

278 But see Allied Finance Co. v. Prosser, 103 Ga. App. 538, 119 S.E.2d 813 (1961), where the Georgia court was willing to deny full faith and credit to a Texas judgment on the ground that the giving of a note in the purchase of an automobile was not sufficient "doing business" to allow Texas, under the fourteenth amendment, to acquire in personam jurisdiction over the individual borrower. Perhaps the smallness of the defendant is an element of "reasonableness."

279116 S.E.2d 910 (W. Va. 1960).

280 III. REv. STAT. ch. $110, \S \S 16,17$ (1959).

281116 S.E.2d at 921.

232 Even if notice is not required, this movement to the new basis of jurisdiction as typified by the Illinois statute. IrI. REV. STAT. ch. $110, \S \S 16,17$ (1959), will probably also be the result of the new venue restrictions placed on cognovit judgments by Illinois and Ohio in recent years. See note 262 supra. Even if these restrictions are not jurisdictional, there probably will be fewer judgments taken against non-residents in those once popular states.

283 Recent developments in both Ohio and Illinois indicate that the respective legislatures of these two states are aware of the inherent unfairness of cognovit judgments. In 1959, Ohio limited venue for cognovit judgments. Ohio Laws 1959, p. 137, now appearing as OHIO REv. CODE ANN. $\$ 2323.13$ (Baldwin 1960). See note 262 supra. In 1961, llinois through a rather 
Some state supreme court must now take the first step and declare a nonnotice cognovit judgment unconstitutional. Then the United States Supreme Court would have a chance to affirm.

The attorney later called up Joe. "Good news! The United States Supreme Court just threw out judgments where notice wasn't given. You won't have to pay Friendly Finance twice."

strange procedure prohibited using cognovit judgment as "the basis for seeking a deduction order" unless the judgment was confirmed by a trial de novo before which the plaintiff had to attempt to give notice. A gentle push from the United States Supreme Court might be sufficient to induce these legislatures to abolish cognovits entirely. 